\title{
A UNIFIED THEORY OF CONSTITUTIONAL FACTS
}

\author{
David L. Faigman*
}

TABLE OF CONTENTS

I. “INTERPRETIVE” FACT-FINDING

II. THE CONFIGURATION OF CONSTITUTIONAL FACTS

A. A Taxonomy of Constitutional Facts

B. Classifying Constitutional Facts

1. Proving Constitutional Rule-Facts

a. Sources of proof

b. Allocating burdens of proof

2. Proving Constitutional Review Facts

a. Sources of proof

b. Allocating burdens of proof

3. Proving Constitutional Adjudicative-Facts

a. Sources of proof

b. Allocating burdens of proof

III. JUDICIAL REVIEW OF CONSTITUTIONAL FACT-FINDING

A. Facts Found by Lower Courts

1. Judicial Review of Constitutional Facts Found at Trial

Professor of Law, University of California, Hastings College of the Law. I would like to thank the many people who read and commented on various drafts of this article. Of particular assistance were the faculty workshops at which I presented the main themes developed here. I am deeply indebted to the participants of the workshops at Arizona State University, The Center for the Study of Law and Society - Boalt Hall, Washington \& Lee University, University of California, Irvine (Social Ecology), University of Texas, Stanford University, and University of California, San Diego (Psychology). Many individuals as well provided invaluable feedback and were very generous with ideas and suggestions. I would like to thank, in particular, Ashutosh Bhagwat, Lawrence Douglas, John Monahan, Roger Park, Michael Saks, Austin Sarat, Chris Slobogin, Scott Sundby, John Robertson, and Wendy Wagner. I also want to thank my wife Lisa, whose sharp editorial eye improved the quality of my writing and saved me from many embarrassing errors.

Portions of this Article were first published in exploratory form as part of the Amherst Speaker Series. See David L. Faigman, Fact-Finding in Constitutional Cases, in How THE LAW KNOWs [Forthcoming, Summer, 2006]. 
2. Juries Within the Constitutional Structure

a. Juries and constitutional values

b. Judging credibility of witnesses

B. Judicial Review of a Legislature's Fact-Finding

C. Lower Court Review of Higher Court Fact-Finding

1. General Considerations

2. Specific Considerations

a. Constitutional rule-facts

b. Constitutional adjudicative-facts

c. Constitutional review-facts

\section{CONCLUSION}

\section{INTRODUCTION}

Western society is now more than three centuries past the scientific revolution, yet courts continue to treat facts, and the scientific methods used to find those facts, much as the Catholic Church did in the time of Galileo. This is especially so in the constitutional arena. The Supreme Court considers the empirical world to be a constituent part of doctrine. ${ }^{1}$ Facts don't so much exist as serve to buttress a world view emanating out of a holy text. In the case of the High Court, that text is the Constitution. But just as the Church lost credibility when it was dismissive of science, the Court endangers its legitimacy by maintaining a jurisprudence that is inattentive to scientific advances. In this Article, I propose both a theoretical justification for an empirically enlightened constitutional jurisprudence and a framework through which such a jurisprudence might be practiced. Given that the Constitution was framed on the principles of the enlightenment, it is about time that the courts enter the scientific age.

1 See David L. Faigman, “Normative Constitutional Fact-Finding”: Exploring the Empirical Component of Constitutional Interpretation, 139 U. PA. L. REV. 541 (1991); see also Rachel N. Pine, Speculation and Reality: The Role of Facts in Judicial Protection of Fundamental Rights, 136 U. PA. L. REV. 655 (1988); Dean M. Hashimoto, Science as Mythology in Constitutional Law, 76 OR. L. REV. 111 (1997); Adam Hoffman, Note, Corralling Constitutional Fact: De Novo Fact Review in the Federal Appellate Courts, 50 DUKE L.J. 1427 (2001); Frank R. Strong, The Persistent Doctrine of "Constitutional Fact," 46 N.C. L. REV. (1968); Frank R. Strong, Dilemma Aspects of the Doctrine of "Constitutional Fact," 47 N.C. L. REV. 311 (1969); Jeffrey M. Shaman, Constitutional Fact: The Perception of Reality by the Supreme Court, 35 U. FLA. L. REV. 236 (1983); Ann Woolhandler, Rethinking the Judicial Reception of Legislative Facts, 41 VAND. L. REV. 111 (1988).. 
The Supreme Court habitually employs factual predicates in its constitutional jurisprudence. ${ }^{2}$ Yet the Court has never developed an intelligible constitutional fact jurisprudence. Indeed, the term itself is often used to describe only one type of fact - casespecific (or adjudicative) facts - when facts operate at multiple levels of constitutional adjudication, from law definition to law application. ${ }^{3}$ No standards apply to courts' reception of constitutional fact-based evidence. Constitutional facts come to courts' attention through expert witnesses, legislative records, and briefs. Juries occasionally decide them and at other times judges do so. There has never been an attempt to set procedural rules for constitutional factfinding. Burdens of proof are left, at best, implicit, and are usually overlooked completely. Moreover, no general rules apply concerning the standard of appellate review of constitutional facts. While a few scholars have weighed in on some of the issues presented by constitutional facts, ${ }^{4}$ the subject remains adrift in an epistemological fog. Fact-finding at the Court seems to occur in the twilight zone between doctrine and its application. Facts do not so much as inform constitutional law as serve doctrinal choices made on other grounds. Inconvenient facts, therefore, are interpreted - molded really - to conform to jurisprudential necessities. The Court's failure to develop a comprehensive constitutional-fact jurisprudence effectively gives it broad latitude to find facts flexibly. The absence of any consistent conception of the place of facts in constitutional cases permits the Court the freedom to employ facts unconstrained by principle.

2 See DAVID L. FAigman, LABORATORY OF Justice: The Supreme Court's 200YeAr StRUGGLE to InTEGRATE SCIENCE AND THE LAW (2004); I. BERNARD COHEN, SCIENCE AND THE FOUNDING FATHERS (1995).

3 I use the term "constitutional fact" to refer to all facts used in constitutional cases, whether they are relied upon to interpret the Constitution or are relevant to the application of particular constitutional provisions. See Section II for a discussion of the different kinds of constitutional facts.

4 The corpus of scholarship on the immense subject of constitutional fact-finding is relatively small, though the subject has interested some better known scholars. See Kenneth Karst, Legislative Facts in Constitutional Litigation, SuP. CT. REV. 75 (1960); Laurence H. Tribe, Seven Deadly Sins of Straining the Constitution Through a Pseudo-Scientific Sieve, 36 Hastings L.J. 155(1984); Henry P. Monaghan, Constitutional Fact Review, 85 ColuM. L. REV. 229 (1985). 
In this Article, I propose a unified theory of constitutional facts. Section I sketches the basic parameters of the Court's current approach to constitutional fact-finding, which closely adheres to what Professor Ronald Dworkin calls "interpretive" fact-finding. It is the Court's manner to treat facts as being highly malleable and to employ them to serve doctrinal ends. Facts do not exist separately from the fact-finder; they are interpreted rather than found. They are largely articles of faith. Interpretive fact-finding has the salutary effect that a changing factual landscape will not endanger settled constitutional precedent. But this is their greatest weakness too, for the Court's approach neither accounts for nor provides a systematic method by which to integrate changed factual understandings into constitutional doctrine. Ultimately, ignoring the empirical component of constitutional adjudication will threaten the legitimacy of the Court's pronouncements.

Constitutional facts come in a variety of forms, with some serving to define the Constitution's meaning and others relevant only in particular cases. Section II describes the different kinds of constitutional fact and discusses their relationship to one another and to constitutional doctrine more generally. In addition, this section examines how different kinds of constitutional fact might be proven in constitutional adjudication. Different facts demand different procedural rules of proof, and this part considers the sources of proof and the sorts of burdens of proof that should apply to the different levels of fact-finding in constitutional cases.

A large component of constitutional fact-finding lies in the dynamic between legal decision-makers. Constitutional facts are found by all those charged with making decisions having constitutional import, including, among others, police officers, school boards, legislatures, juries, trial court judges, and appellate courts. A unified theory of constitutional facts must account for the highly complex dynamic between these various decision-makers. Section III considers this issue as regards facts found (or reviewed by) courts, up, down, and across the judicial hierarchy. This part focuses on three principal areas in which this dynamic is most prominent in constitutional adjudication. First, it examines judicial review of constitutional 
facts found at trial and, in particular, the jury's role in the constitutional law dynamic. Second, it examines possibly the highest profile situation in constitutional adjudication, that of judicial review of a legislature's constitutional fact-finding. Finally, this section turns to possibly the most controversial - and surely the most interesting - subject involving constitutional factfinding, whether lower courts can sometimes review the fact-finding of higher courts, and thereby depart from precedent when the facts, or our knowledge of the facts, change.

\section{I. “INTERPRETIVE”' FACT-FINDING}

Fact-finding is an essential component of both constitutional interpretation and constitutional application. Historically, however, courts and commentators have sought to avoid this essential truth - and for good reason. Facts are highly indeterminate and they inevitably destabilize the sought-after stability of fundamental constitutional values. For instance, many commentators were highly critical of the Supreme Court's seeming reliance on social science research in Brown v. Board of Education. ${ }^{5}$ In concluding that segregated schools were "inherently unequal," the Brown Court cited the work of Dr. Kenneth Clark and others that indicated that blacks suffered psychological harm as a result of segregation. ${ }^{6}$ Many prominent commentators challenged the Court's use of science on the basis either that the findings were obvious or largely irrelevant. Professor Ronald Dworkin, for example, beginning with a premise from another scholar, argued both of these together:

"We don't need evidence for the proposition that segregation is an insult to the Black community - we know it; we know it the way we know that a cold causes snuffles." It is not that we don't need to know it nor that there isn't something there to know. There is a fact of the matter, namely that segregation is an insult, but we need no evidence for that

5347 U.S. 433 (1954). See, e.g., Edmund Cahn, "Jurisprudence," 30 N.Y.U. L. REV. 150, 157-58 (1955) ("I would not have the constitutional rights of Negroes - or of other Americans - rest on any such flimsy foundation as some of the scientific demonstrations in these records.").

$6 \quad$ Brown, 347 U.S. at 494 n.11. 
fact - we just know it. It's an interpretive fact. ${ }^{7}$

Dworkin's term "interpretive fact" is a component of a legal theory he calls "creative" or "constructive" interpretation. ${ }^{8}$ He analogizes constitutional interpretation to the writing of the latest chapter of a chain novel. ${ }^{9}$ The interpreter fits his or her interpretations into the prior chapters and, at the same time, extends the overall work in the "best possible" direction. The theory contemplates first that the interpreter identify the "fit" between the interpretive history and the practice being interpreted and, second, that the interpreter impose a "purpose on an object or practice in order to make of it the best possible example of the form or genre to which it is taken to belong."

The difficulty in Dworkin's formulation, for present purposes, lies in understanding the role of science in this legal-interpretive discourse. Science certainly is used by the law as a means to accomplish certain objectives. But science, at least good science, does not permit any interpretation the interpreter desires, much less the "best possible." Although science cannot entirely divorce itself from its social context, sound science and reputable scientists have no preset agendas about the proper shape that the world should take. The law, in contrast, is

$7 \quad$ Ronald Dworkin, Social Sciences and Constitutional Rights - The Consequences of Uncertainty, J. L. \& EDUC. 6 (1977): 3, 5 (quoting Cahn, supra note XX, 157-58).

$8 \quad$ A second component of Dworkin's notion of interpretive facts is his belief that the social sciences are not sufficiently valid to support constitutional rulings. For example, Dworkin argues that "[w]hile in physics it is now thought to be an unsound judgment that rests merely on correlation between observable events unsupported by some notion of the mechanics that translate the cause to the effect, social science is only able to provide correlations without the mechanics." Id. Dworkin's criticism displays an unhealthy amount of "physics envy." See David L. Faigman, To Have and Have Not: Assessing the Value of Social Science to the Law as Science and Policy, 38 EMORY L.J. 1005 (1989).

9 RONALD DWORKIN, LAw's EMPIRE (1986). See also Ronald Dworkin, Law as Interpretation, 60 TEX. L. REV. 527, 540-46 (1982). For an analysis of the chain novel metaphor, see Stanley Fish, “Working on the Chain Gang' Interpretation in Law and Literature,” TEX. L. REV. 60 (1982): 551.

10 Dworkin (1986), supra note XX, at 52. 
primarily about setting such agendas. Whereas the insult associated with segregation may be plain legally (at least after 1954), just how plain it is as a matter of science depends on the data. How, then, should scientific interpretation be combined with legal interpretation? Although Dworkin has yet to address this specific issue, his chain of logic can be considered in regard to its application to the matter at hand.

If, as Dworkin apparently accepts, "there is a fact of the matter," even such a fact as the insult attributable to segregation, when is that "real-world" fact relevant and when is its interpretive cousin relevant? If all constitutional facts are repackaged under Dworkin's definition as merely interpretive facts, this solves one problem by creating another one. It solves the problem inherent in basing constitutional doctrine on indeterminate and changeable factual premises. Accordingly, in the Brown example, it would not matter what quantum of evidence might later be adduced to demonstrate the salutary attributes of state-sponsored segregation. If the fact is interpretive, no amount of data could ever disprove the "fact" that segregation is insulting. It is so, like other constitutional matters, because the Court says so. The problem this fact-finding by fiat creates, however, is the almost certain erosion of the legitimacy of Court pronouncements. Despite the elegance of Dworkin's efforts, the empirical world still exists outside the Court's dictates. Facts are what they are, and the Court's insistence otherwise makes it appear dogmatic.

Dworkin's approach relies on an expansive notion of "facts." In his view, facts are elastic enough to be able to serve the normative needs of the Constitution. But the question is, can we make facts mean whatever we want them to mean? Dworkin seems to vacillate between describing constitutional facts as a function of normative judgment and believing them to be a matter of common sense experience. But the former - "normative facts" - are reminiscent of the practices of the Sixteenth Century Catholic Church, and the latter resemble a caricatured version of the Seventeenth Century inductive methods of Francis Bacon. We may know, as Dworkin argues we should know "interpretively," "that a cold causes snuffles." But surely, if the "interpretive" judgment is accurate, valid scientific studies should corroborate that judgment. 
Science is not irrelevant for demonstrating what everyone believes to be the case, though courts might wish to relegate studies corroborating the relationship between a cold and snuffles to a footnote. And some day, to our surprise, it might turn out that a malady only associated with colds causes snuffles, and that we were wrong the whole time. Certainly, researchers should not be discouraged from studying the question on the basis that we know it to be true because we know it to be true.

In practice, of course, so-called "interpretive facts" play a steadying role. This utility is their virtue. Seen as an interpretive fact, the deleterious effects of segregation are not open to reexamination. An interpretive fact thus corresponds neatly with traditional notions of constitutional doctrine, in that neither need change except by dictate of the Court. Real facts, in contrast, are mercurial. Given their proclivity for change, either because our knowledge of the facts improves over time or the facts themselves change, they seem to provide a disturbingly unsteady foundation for constitutional doctrine. Described as a factual matter, therefore, the holding in Brown that blacks are disadvantaged by segregation would appear vulnerable to refutation by well-designed studies that indicate that blacks are not disadvantaged or, even, are better off with this practice. This is probably not an occurrence to which the Court gave much thought when drafting the Brown opinion. Almost certainly, the justices would have agreed with the gist of Dworkin's argument, that changing facts regarding segregation's insult did not undermine the continuing validity of Brown. This proposition, however, was eventually tested in a courtroom in Savannah-Chatham, Georgia.

In 1963, in Stell v. Savannah-Chatham, ${ }^{11}$ the county defended a desegregation suit on the basis that black children were not, in fact, psychologically harmed by attending segregated schools. The plaintiffs argued that the district court had no discretion to reopen this factual question. According to the plaintiffs, it had been conclusively determined by the Supreme Court in Brown that segregation harmed black children. The trial court in Stell disagreed. The court explained that the lower court in Brown had found that "segregation with the sanction of law ...

220 F.Supp. 667 (S.D.Ga. 1963). 
has a tendency to (retard) the educational and mental development of Negro children and to deprive them of some of the benefits they would receive in a racial[ly] integrated school system.,"12 The judge stated, "[t]hese are facts, not law," explaining:

Whether Negroes in Kansas believed that separate schooling denoted inferiority, whether a sense of inferiority affected their motivation to learn was increased or diminished by segregation was a question requiring evidence for decision. That was as much a subject for scientific inquiry as the braking distance required to stop a two-ton truck moving at ten miles an hour on dry concrete. ${ }^{13}$

Based on the expert testimony introduced in the case, the trial court concluded that "prejudices, whether ethnic, religious or racial, increase rather than decrease in proportion to the degree of non-voluntary contact between separately identifiable groups."14 The court said that this "is a psychological phenomenon which was noted in the time of Periclean Greece."15 Moreover, modern "studies made of actual intermixing of groups in classrooms confirm the predicted result that an increase in cross-group contacts increases pre-existing racial hostility rather than ameliorates it."16

On appeal, the Fifth Circuit summarily reversed the Stell district court. The appellate court admonished that "no inferior federal court may refrain from acting as required by [the Brown] decision even if such a court should conclude that the Supreme Court erred either as to its facts or as to the law."17 Moreover, the circuit court discounted the importance of the social science evidence for the Brown result. "We do not read the major premise of the decision of the Supreme Court in the first Brown case as being limited to the facts of the cases there presented.
$12 \quad$ Id. at $677-78$.
$13 \quad I d$. at 678.
$14 \quad$ Id. at 674.
$15 \quad I d$.
$16 \quad I d$.
$17 \quad 333$ F.2d 55, $61\left(5^{\text {th }}\right.$ Cir. 1964). 
We read it as proscribing segregation in the public education process on the stated ground that separate but equal schools for the races were inherently unequal." ${ }^{\prime 18}$

The Fifth Circuit effectively understood Brown "interpretively," in that the facts set forth in 1954 had become established law a decade later. ${ }^{19}$ This creative approach to constitutional facts can be found in many cases. ${ }^{20}$ Typically, the Court's first entry into a particular constitutional arena involves an ostensibly serious evaluation of the relevant factual underpinnings of the eventual holding. Subsequently, however, the precedent hardens into established constitutional doctrine and, as a consequence, the factual premises petrify. ${ }^{21}$ If the relevant facts were not "interpretive" at the start, they become so once the case has entered the lexicon of settled law.

Treating facts interpretively solves the problem of having changeable constitutional standards due to a changing understanding of the empirical world. The factual premises are "interpreted" in conformance with the constitutional outcome, notwithstanding evidence to the contrary. But this stability comes at a cost. A rule that has outlived its reasons for being is correctly seen as illegitimate. As various justices have lamented, advancing technology threatens the stability of established precedent in a multitude of constitutional contexts. ${ }^{22}$ If, for example,

$18 \quad I d$.

19 The latter argument - that the major premise of Brown depended on the normative proposition that segregated schools were "inherently unequal" - effectively reads the factual dispute out of the decision.

20 See generally, Faigman (1991), supra note XX.

21 See, e.g., Akron v. Akron Center for Reproductive Health, 462 U.S. 458 (1983) (Despite changes in medical technology that permitted abortions in 1983 to be performed more safely than childbirth through at least week 16, the Court held that "[ $\mathrm{t}$ ]he Roe trimester standard ... continues to provide a reasonable legal framework for limiting a State's authority to regulate abortions.”); United States v. Salerno, 481 U.S. 739, 751 (1987) (““[T]here is nothing inherently unattainable about a prediction of future criminal conduct." (quoting Schall v. Martin, 467 U.S. 253, 276 (1984)).

22 See, e.g., Ashcroft v. ACLU, 124 S.Ct. 2783 (2004). See generally Stuart Minor $-10-$ 
the right of reproductive choice is based on the medical concept of viability - the time after which a fetus is likely to survive outside the womb - the Court's failure to follow advancing technology will undermine the cogency of the precedent. The rule in Roe $v$. Wade $e^{23}$ provides that states cannot prohibit abortions pre-viability, a point-in-time of around 24-28 weeks in 1973 and closer to 22-24 weeks today. However unlikely a technological revolution in viability might appear today, advances in this area could move viability considerably closer to conception. ${ }^{24}$ If a woman's basic right of choice is truly based on the values associated with viability, then presumably the right should change as technology changes.

But such a changeable constitutional jurisprudence could itself be derided as illegitimate. ${ }^{25}$ Dworkin's interpretive fact approach ingeniously resolves this dilemma, since interpretive facts are as solid as the doctrine demands or as flexible as they need to be in order to allow the doctrine to evolve. Under this approach, because constitutional facts are "interpreted" and not "found," justices can employ them with little fear that future researchers might call into question the premises of their handiwork.

Yet, the world does not always cooperate with the wishes of the justices or constitutional scholars. At least on occasion, scientists will demonstrate the errors in the Court's factual premises with enough certainty to engender doubt over the soundness of the Court's logic. Indeed, this can be expected to occur with increasing frequency as basic scientific methods improve or the Court finds facts that are amenable to more definitive proof. Opinions that employ facts interpretively are more reminiscent of holy writ than reasoned and informed legal

Benjamin, Stepping Into the Same River Twice: Rapidly Changing Facts and the Appellate Process, 78 TEX. L. REV. 269 (1999).

23410 U.S. 113 (1973).

24 See generally LAURENCE H. TRIBE, ABORTION (1990).

25 See Washington v. Glucksberg, 521 U.S. 702, 754 (1997) (Souter, J., concurring) (discussing need to avoid establishing constitutional standards on factual premises that might change as more research is done). 
judgment. But there is no inherent contradiction between enlightened factual investigation and a cogent constitutional jurisprudence. Constitutional doctrine should be informed by contemporary understandings of the empirical world. By necessity, such an approach would take into account the dynamic nature of fact-finding and science, albeit in combination with the critical need for some measure of steadiness in constitutional doctrine.

Just how much unsteadiness would be created by a changeable factual landscape depends on the kinds of facts that are changing. Some facts are used to establish the Constitution's meaning and underlie the doctrines that apply to all similarly situated claims. When these facts change, whole areas of jurisprudence might be affected. Other facts have more limited scope, involving only the immediate dispute and concern what happened to whom, where, and why. These facts would have little impact across constitutional cases when they fluctuated. A workable jurisprudence of fact-finding must account for every type of fact, and this, in turn, must begin with the subject of the next section: categorizing the kinds of facts employed in constitutional claims.

\section{THE CONFIGURATION OF CONSTITUTIONAL FACTS}

The Constitution was intended, and is generally considered, to be an eminently practical document, so legal rules and decisions springing from it ought to be informed by the best evidence available. Facts, whether they are the function of decades of Nobel-level research or the anecdotal observations of a police officer, come to the legal system in a wide variety of ways. Constitutional facts arrive in court through lay witnesses and expert testimony at trial, congressional (or other legislative) hearing testimony, amicus briefs, a court's own research, and many others. In court, constitutional facts might be the subject of jury deliberations, judicial determination, de novo appellate review, or some combination of all of these. The dynamic among the different decision-makers ultimately depends upon the kinds of factual matters that the Constitution makes relevant. Thus, as presented in Brown, whether the empirical 
consequences of segregation by race are relevant in the first instance is a matter of constitutional interpretation. Moreover, whether the focus is on the consequences at a particular school in a particular city or on those effects nationally, is also a matter of constitutional interpretation. ${ }^{26}$ In this section, I describe a framework by which the full range of constitutional facts can be classified. Only once they have been sorted can an intelligible jurisprudence be applied to them.

\section{A. A Taxonomy of Constitutional Facts}

In a landmark article, Professor Kenneth Culp Davis identified two basic kinds of facts having evidentiary significance. ${ }^{27}$ The first he termed "legislative facts," and the second he called "adjudicative facts." According to Davis, legislative facts are those facts that have relevance to legal reasoning and the fashioning of legal rules. ${ }^{28}$ Adjudicative facts, in contrast, are relevant to the resolution of particular cases. In a later text, Davis explained, "[a]djudicative facts usually answer the questions of who did what, where, when, how, why, with what motive or intent.... Legislative facts do not usually concern the immediate parties but are general facts which help the tribunal decide questions of law and policy and discretion." ${ }^{29}$ Judges typically decide questions of legislative fact. ${ }^{30}$ Adjudicative facts, on the other hand, are usually within

26 See infra note XX (discussing confusion during oral argument in Brown as to whether the challenge to segregation was based on evidence that applied generally or that only concerned the locales that were the subject of the litigation).

27 Kenneth Culp Davis, An Approach to Problems of Evidence in the Administrative Process, 55 HARV. L. REV. 364, 402-03 (1942).

28 See FED. R. EVID. 201(a) advisory committee's note ("Legislative facts ... are those which have relevance to legal reasoning and the lawmaking process, whether in the formulation of a legal principle or ruling by a judge or court or in the enactment of a legislative body.").

29 Kenneth Culp Davis, Administrative LAW TeXt, $§ 7.03$, at 160 (3d ed. 1972).

30 See id.; see also Davis, supra note XX, at 402 (noting that the rules of evidence for finding facts that form the basis for creation of law and policy should differ from the rules for finding facts specific to parties in a particular case). 
the province of the trier of fact (the jury or, if there is no jury, the judge) to decide. ${ }^{31}$

A key distinguishing feature between legislative and adjudicative facts is the level of decision-making at which the asserted facts are relevant. Whereas legislative facts ordinarily relate to matters that transcend individual disputes and would likely recur in different cases involving similar subjects, adjudicative facts ordinarily are peculiar to a particular case. ${ }^{32}$ In McCleskey v. Kemp, ${ }^{33}$ for example, the petitioner claimed that Georgia's capital sentencing scheme discriminated on the basis of the race of the victim. This allegation was based on an extensive and sophisticated study conducted by David Baldus and his colleagues. Among other things, Baldus concluded that, all things being equal, "defendants charged with killing white victims were 4.3 times as likely to receive a death sentence as defendants charged with killing blacks." 34 This discrimination claim was based on legislative facts, in that it was directed at the Georgia system as a whole and McCleskey offered no evidence that he personally was a victim of discrimination. As Justice Powell, writing for the Court, pointed out, "[e]ven Professor Baldus does not contend that his statistics prove ... that race was a factor in McCleskey's particular

31 Professors John Monahan and Laurens Walker expanded upon the Davis dichotomy by adding a third category that they call "social frameworks." Laurens Walker and John Monahan, Social Frameworks: A New Use of Social Science in Law, 73 VA. L. REV. 559, 563-570 (1987).

32 The reason I say "ordinarily" is that there is a basic ambiguity inherent in Davis' categories. His division of facts into legislative and adjudicative categories is based on how the fact-finder employs the particular fact. If the fact is used to resolve a particular litigation, it is, by definition, "adjudicative." This is so even though the factual issue may transcend a particular dispute, such as whether second-hand smoke causes lung cancer or silicone implants cause autoimmune disorders. Similarly, if a legislature points to a particular case to support its lawmaking - as occurred in the "right-to-die" controversy involving Terri Schiavo in 2005 - this particularized fact is, by definition, "legislative." The scheme I develop in this section for the constitutional arena largely avoids this ambiguity, because the generality or specificity of the factual inquiry operates as the definitional feature of my framework.

33481 U.S. 279 (1987).

$34 \quad$ Id. at 321. 
case."35 Indeed, of great concern for the Court was that "McCleskey's claim, taken to its logical conclusion, throws into serious question the principles that underlie our entire criminal justice system." ${ }^{36}$ Legislative facts, as their name connotes, typically have broad impact across large areas of the law.

How the constitutionally relevant inquiry is described, therefore, as being at either the adjudicative or legislative level, obviously is of great importance. In principle, the Constitution itself establishes what sorts of facts are relevant under its dictates. In other words, the description of the relevant factual inquiry under a particular provision of the Constitution is a matter of interpretation. In the cases leading up to McCleskey, for instance, the Court had indicated that substantial evidence of systemic discrimination would constitute an Eighth Amendment violation. ${ }^{37}$ The relevant facts under this earlier interpretation of the Eighth Amendment, then, were legislative in character. In McCleskey, however, the Court stepped away from this precedent. In its new interpretation of the Eighth Amendment, the Court redefined the level of relevant fact-finding. The McCleskey Court said that the relevant facts under the Eighth Amendment were case specific, or adjudicative, and held that claims of systemic discrimination were insufficient to sustain a cause of action. Under both the Eighth and Fourteenth Amendments, according to the Court, claimants had to demonstrate individualized discrimination.

Davis' dichotomy generally describes the kind of fact-finding that occurs in constitutional cases and it has become the established vocabulary for describing the kinds of facts that are relevant to legal discourse. ${ }^{38}$ My approach roughly parallels Davis', though the constitutional

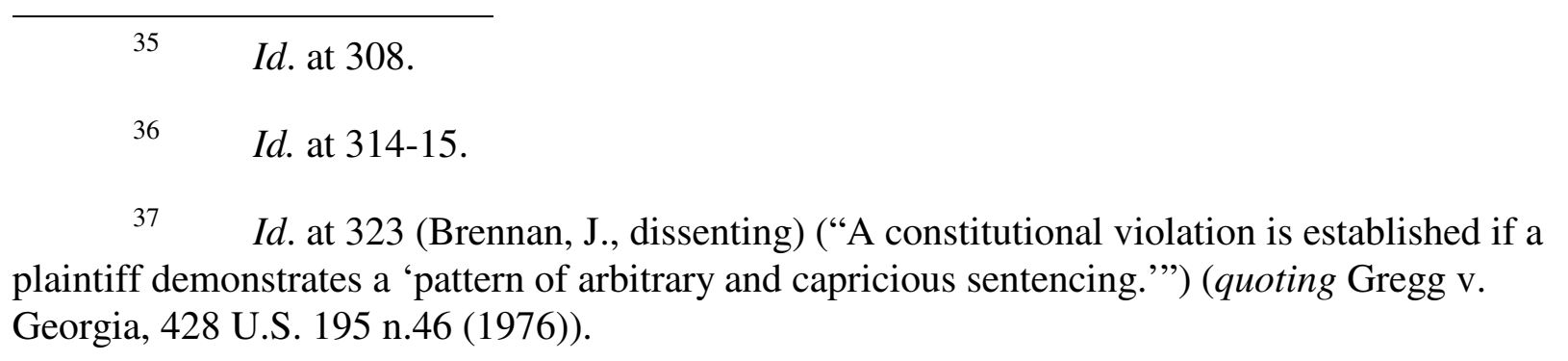

38 Judge Robert Keeton has suggested the use of the term "premise facts" to describe -15 - 
arena requires refinement of his scheme. Davis' legislative fact category can be further distilled in the constitutional context into two subcategories, "constitutional rule-facts" and “constitutional review-facts." 39 This revision turns out to have special relevance for constructing procedural rules in constitutional cases. ${ }^{40}$

Constitutional rule-facts are advanced to substantiate a particular interpretation of the Constitution. Constitutional rule-facts join, and sometimes are a component of, the traditional sources of authority - the text, original intent, constitutional structure, precedent, scholarship, and contemporary values - in establishing the meaning of the Constitution. ${ }^{41}$ Indeed, one of the most common bases for constitutional interpretation, original intent, is almost wholly fact-based. Most debates over original intent resolve down to disagreements over historical facts, such as whether the drafters or ratifiers of the Fourteenth Amendment expected the Equal Protection Clause to invalidate segregated public schools ${ }^{42}$ or whether the Free Speech Clause was intended to cover obscenity. ${ }^{43}$ In addition, many arguments based on constitutional structure depend either implicitly or explicitly on hypotheses that might be the subject of political science or sociology. John Marshall's assertion in Marbury v. Madison, ${ }^{44}$ for instance, that legislators are

any facts that support a reasoned decision of law or policy." Robert E. Keeton, Legislative Facts and Similar Things: Deciding Disputed Premise Facts, 73 MinN. L. REV. 1, 11 (1988).

39 [Identifying footnote removed.]

40 See Section III, infra (discussing different standards for when lower courts should have the authority to reconsider constitutional legislative facts depending on whether they are rule-facts or review-facts).

41 See Faigman, supra note XX, at 542-44; See generally Richard H. Fallon, Jr., A Constructivist Coherence Theory of Constitutional Interpretation, 100 Harv. L. Rev. 1189, 124446 (19XX); Michael Perry, The Authority of Text, Tradition, and Reason: A Theory of Constitutional “Interpretation," 58 CAL. L. REV. 551, 552 (1985).

$42 \quad$ See Brown v. Board of Education, 347 U.S. 433 (1954).

43 See Paris Adult Theatre v. Slaton, 413 U.S. 49 (1973).

$44 \quad 5$ U.S. 137 (1803). 
less likely than judges to be bound by a written constitution, is a rule-fact of this sort. ${ }^{45}$ Rulefacts, therefore, are employed to determine or justify the development of rules or standards that apply to all similarly situated cases. Constitutional doctrine, of course, is replete with examples of such rules, including tiered-scrutiny in due process and equal protection, the Millertest for obscenity, ${ }^{46}$ Brandenburg's incitement test, ${ }^{47}$ Crawford's test of testimonial evidence under the Confrontation Clause, ${ }^{48}$ and so on. Many of these were developed, in part, on the basis of factual arguments. Moreover, virtually all of them establish constitutional inquiries that are answerable only by review-facts or adjudicative-facts.

Constitutional review-facts embody the more generally recognized function of legislative fact-finding in constitutional cases. Courts examine constitutional review-facts under the pertinent constitutional rule or standard in order to determine the constitutionality of some state or federal action. Review-facts transcend particular disputes and thus can recur in identical form in different cases and varying jurisdictions. Under the Commerce Clause, for instance, the applicable standard asks, among other things, whether the federal law "substantially affects interstate commerce." 49 A good example comes from Gonzales v. Raich, ${ }^{50}$ in which the Court determined whether Congress had the authority under the Commerce Clause to regulate the home production of marijuana. Under the applicable standard, the Court had to consider whether Congress had a rational basis for concluding that home production of marijuana substantially affects price and national market conditions for marijuana. ${ }^{51}$ After reviewing the record and

$45 \quad$ Id. at 137 ("The powers of the legislature are defined, and limited; and that those limits may not be mistaken, or forgotten, the Constitution is written").
46
Miller v. California, 413 U.S. 15 (1973).
47
Brandenburg v. Ohio, 395 U.S. 444 (1969).
48
Crawford v. Washington, 541 U.S. 36 (2004).
49
Wickard v. Filburn, 317 U.S. 111, 128-29 (1942).
50
125 S.Ct. 2195 (2005).
51
Id. at 2197. 
Congress" reasons for regulating, the Court concluded that "the regulation is squarely within Congress' commerce power because production of [marijuana] ... has a substantial effect on supply and demand in the national market for that commodity." ${ }^{, 52}$ The Court explained that "[o]ne need not have a degree in economics to understand why a nationwide exemption for the vast quantity of marijuana ... locally cultivated for personal use (which presumably would include use by friends, neighbors, and family members) may have a substantial impact on the interstate market for this extraordinarily popular substance." ${ }^{53}$ The Court concluded that "Congress' judgment is not only rational, but 'visible to the naked eye,' under any commonsense appraisal of the probable consequences of such an open-ended exemption." 54

Constitutional rule-facts and constitutional review-facts involve factual determinations that transcend particular cases and are relevant to either the formation of a constitutional rule or the application of a rule to similarly occurring cases, respectively. Constitutional adjudicativefacts, in contrast, refer to factual determinations that are relevant to the application of constitutional rules in particular cases. For example, the question whether a police department "intentionally discriminated" against black police officers when it made promotion decisions based on an exam on which whites received significantly higher scores raises a constitutional adjudicative-fact issue. Similarly, the likely consequences of Nazis marching through a predominantly Jewish neighborhood in Skokie, Illinois would be a constitutional adjudicativefact. Adjudicative-facts, as their name implies, are specific to a particular proceeding and their resolution has limited precedential import.

Unfortunately, no bright lines mark the boundaries between different kinds of constitutional facts. Because the procedural standards developed in Section III depend on these categorizations, however, ambiguity in this area is a matter of some consequence. More
$52 \quad$ Id. at 2197.
$53 \quad$ Id. at 2212.
$54 \quad$ Id. (quoting Lopez, 514 U.S. at 563). 
problematic still, uncertainty surrounding categorization arises across the entire spectrum of constitutional facts. The process of determining what facts are constitutionally relevant and what category they fall into must be determined on a case-by-case, or constitutional-provision by constitutional-provision, basis. The next section explores the variables by which constitutional facts might be classified and the vagaries that attach to that scheme.

\section{B. Classifying Constitutional Facts}

Constitutional rule-facts are marked by their relevance to the formation or justification of constitutional rules or standards. Recognizing a constitutional rule-fact as such often will be fairly straightforward. One of the most famous examples of a constitutional rule fact comes from the litigation of Brown v. Board of Education. The case was first heard during the Court's 195253 term. Led by Chief Justice Vinson, a divided Court held the case over to the following term. The Court issued a series of questions for the parties to answer upon re-argument. Several of these were directed at the historical question whether the drafters of the Fourteenth Amendment had intended to invalidate segregated public schools by guaranteeing the equal protection of the laws. ${ }^{55}$ In the opinion, Chief Justice Earl Warren, who had replaced Vinson, found that the historical materials were "not enough to resolve the problem with which we are faced. At best, they are inconclusive. ${ }^{, 56}$ The historical fact of the drafters' and ratifiers' intentions regarding the scope of the Fourteenth Amendment was thus ostensibly relevant to the meaning it was to be given, though in the end the Court believed that these facts were known with too little certainty to be relied upon. Other authorities would have to be used.

$55 \quad$ Historians have since discovered that the Court was never particularly interested in the answer to this question, since, even before reargument, a majority supported invalidating segregation on other grounds. See Richard Kluger, Simple Justice (1975). But the year delay had monumental consequences. Chief Justice Vinson died that summer and was replaced by Earl Warren. Chief Justice Warren orchestrated a unanimous opinion in the case that has come to symbolize the inception of modern constitutional jurisprudence. See generally MichaEL J. KLARMAN, From Jim CROW TO CiviL Rights (2004).

Brown, 347 U.S. at 489. 
Rule-facts and review-facts both transcend individual cases, but the former are distinguishable on the basis that they are relevant to the definition of a constitutional rule, whereas the latter are relevant under some already defined constitutional rule. Frequently, however, the line between constitutional rule-facts and constitutional-review facts is indistinct. The more controversial factual issue in Brown involved the Court's citation to research indicating the negative effects of segregation on black school children. But was this evidence used to support a categorical rule prohibiting segregation by race, or was it proof that was relevant under a different rule, one that queried whether the state had a sufficient justification for its discriminatory treatment? The cases decided immediately after Brown suggest the former interpretation, that the studies were employed in service of a new per se rule prohibiting segregation by race. After all, following Brown, the Court invalidated discrimination in a wide variety of public contexts and, along the way, never again mentioned social science data. ${ }^{57}$ Under this interpretation, the social science of Brown, to the extent that it had any value at all, was merely employed to justify a new rule of law.

With the benefit of hindsight, however, it appears that the constitutional issue of segregation's effects is a review-fact and not a rule-fact. ${ }^{58}$ The modern rule provides that

$57 \quad$ See New Orleans City Park Improvement Ass'n v. Detiege, 358 U.S. 54 (1958) (per curiam) (parks and recreational facilities); Gayle v. Browder, 352 U.S. 903 (1956) (per curiam) (buses); Holmes v. City of Atlanta, 350 U.S. 879 (1955) (per curiam) (golf courses); Mayor of Baltimore City v. Dawson, 350 U.S. 877 (1955) (per curiam) (beaches and bathhouses); see also Burton v. Wilmington Parking Authority, 365 U.S. 715 (1961) (holding unlawful racial discrimination in restaurants in public buildings).

$58 \quad$ At oral argument in Brown, there was some confusion regarding whether segregation's effect was an adjudicative fact or a legislative fact. In the trials below, the petitioners had produced evidence on both issues, introducing general social science research conducted years earlier and also litigation-generated research in which students in the respective jurisdiction were tested using Kenneth Clark's notorious doll-tests. At the argument, the NAACP's Robert Carter asked the Court to abide by the Topeka case's finding of fact that segregation had deleterious psychological consequences. He told the Court that the district judge's factual findings make a reversal "necessary." He argued, "[i]f there [are inequalities] in fact, that educational opportunities cannot be equal in law." Justice Hugo Black asked him whether that was " "a general finding or do you state that for the State of Kansas, City of Topeka?" Surprisingly, Carter told the justices that "the finding refers to the State of Kansas and to these appellants and to Topeka, Kansas." He added, "I think that the findings were made in this specific case referring to this specific case." Black was troubled by the ramifications of $-20-$ 
discrimination by race (or segregation) is unconstitutional unless the state's scheme is justified by a compelling objective and the means used are closely tied to achieving that end. ${ }^{59}$ If Michigan, for example, were to create an all-black high school in Detroit that emphasized an African-American curriculum, the state's means and ends would be strictly scrutinized rather than invalidated under some per se rule emanating from Brown and its progeny. Presumably, any defense of this segregation scheme would be based largely on social science research regarding the benefits that would accrue to black students from a segregated high school education. ${ }^{60}$ The rule of Brown and its progeny seems to be that segregation by race is highly suspect, but that it may be possible for a state to justify such disparate treatment if its reasons are sufficiently compelling. But, admittedly, the matter is not free of all ambiguity. Nothing inherent in a particular constitutional fact dictates whether it is a rule- or review-fact. Categorization depends on how a particular court employs the fact, and this might only be determined in particular constitutional contexts by subsequent case law. ${ }^{61}$

limiting the empirical lesson to the single case of Topeka and asked whether this meant that "then you would have different rulings with respect to the places to which this applies, is that true?" Carter quickly realized his error, though in his haste to backtrack he too readily abandoned the general social science available. He argued, "[n]ow, of course, under our theory, you do not have to reach the finding of fact or a fact at all in reaching the decision because of the fact that we maintain that this is an unconstitutional classification being based upon race and, therefore, it is arbitrary." MARK Whitman, ed., REMOVING A BADGE OF SLAVERY 131-32 (1993).

59 See, e.g., Adarand Constructors, Inc. v. Pena, 515 U.S. 200 (1995) (applying strict scrutiny to race-conscious affirmative action programs).

60 See, e.g., United States v. Virginia, 518 U.S. 515 (1996) (In this case involving gender segregation at VMI, much of the litigation proceeded on the assumption that the State could, if its reasons were compelling enough, justify separate military training for men and women.).

61 The sometimes ambiguous character of constitutional facts complicates the task of establishing a rational constitutional-fact jurisprudence, but it is not fatal to that effort and this level of uncertainty is not unknown in constitutional cases. Consider, for example, the longstanding debate over whether the Miranda rule was constitutionally mandated or a judicially enacted remedy that could be revisited by legislative majorities. This ambiguity remained in the law for more than 30 years. Compare Miranda v. Arizona, 384 U.S. 436 (1966) (setting forth the now-famous "Miranda warning," but leaving open the question whether it was constitutionally based) with Dickerson v. United States, 530 U.S. 428, 444 (2000) ("Miranda announced a 
The line distinguishing constitutional adjudicative-facts from other constitutional facts can also be elusive. In principle, adjudicative facts should be readily recognizable. Constitutional adjudicative-facts involve only the case before the respective court and their resolution should have little or no precedential value. Under the Millertest, for instance, one of three necessary findings of fact involves whether the allegedly offending materials appeal to the prurient interest. ${ }^{62}$ This fact is determined on a case-by-case basis in light of local community standards. A finding in a Lexington, Virginia court that a particular Mapplethorpe photograph is obscene, therefore, does not bind a court in Richmond, Virginia that might be evaluating the same photograph. Similarly, in a libel action under New York Times v. Sullivan, ${ }^{63}$ the question whether a false statement was made with "actual malice" will be unique to that particular case. Categorizing a fact as adjudicative or legislative will often be a straightforward exercise.

On occasion, however, determining whether a particular constitutional fact is adjudicative in character will not be obvious. Another component of the Millertest illustrates this very point. The third prong of the test requires, for a finding of obscenity, that "the work, taken as a whole, lacks serious literary, artistic, political, or scientific value."64 Although this fact is to be determined in individual cases for specific materials in dispute, the question involves matters that transcend particular cases. Whether Nabokov's Lolita, for instance, has serious literary or artistic value is a fact of general import, and is not readily classified into either the review-fact or adjudicative-fact bins. In the end, the decision whether to label a particular fact as adjudicative or otherwise may depend on what procedural path the court wants the fact to walk. ${ }^{65}$

constitutional rule that Congress may not supersede legislatively."). At the same time, however, because I prescribe very different rules of procedure for the different kinds of constitutional facts, any ambiguity over what kind of facts are at stake will increase the uncertainty endemic to the process.

62 Miller v. California, 413 U.S. 15 (1973).

$63 \quad 376$ U.S. 254 (1964).

$64 \quad$ Miller, 413 U.S. at 15.

65 This is the lesson that Professors Ronald Allen and Michael Pardo draw - and advocate - in their excellent article on the law-fact distinction. Ronald J. Allen \& Michael S. 
The very act of classifying a fact as a rule-, review-, or adjudicative-fact is an interpretive exercise. A good example of the freedom inherent in classifying constitutional facts, and the policy ramifications that follow from such classifications, comes from the Court's standard for reviewing the constitutionality of abortion regulations. In Planned Parenthood of Southeastern Pennsylvania v. Casey, ${ }^{66}$ the Court ruled that regulations that impose an undue burden on the exercise of the right to a pre-viability abortion are unconstitutional. The undue burden standard was operationally defined to include any regulation that created a "substantial obstacle" to the exercise of the right. ${ }^{67}$ In Casey, the Court invalidated the spousal notification provision of the disputed law applying this rule. The opinion for the Court, written jointly by Justices O'Connor, Kennedy, and Souter, treated the issue as a review-fact, finding that research indicated that domestic violence might occur in a small percentage of cases as a result of this notification requirement. There was no suggestion that the claimants before the Court had experienced, or were in danger of suffering, violence due to the spousal notification requirement. Yet the prospect of such violence in the class of possible complainants, even if it constituted only a small percentage of cases, was enough to invalidate the law in all cases. ${ }^{68}$

At the same time, the Casey Court upheld the 24-hour waiting provision, finding the proof inadequate to conclude that such requirements unduly burden the right. But does this issue implicate a review-fact or an adjudicative-fact and, if the former, was the appropriate domain the nation or the state? In a Woman's Choice-East Side Women's Clinic v. Newman, ${ }^{69}$ the Seventh Circuit offered a confusing, if not confused, answer to this question. The district court had enjoined Indiana's informed consent law shortly after it was enacted on the basis that it would

Pardo, The Myth of the Law-Fact Distinction, 97 Nw. U. L. REV. 1769 (2003).
66 505 U.S. 833 (1992).
$67 \quad I d$. at 846.
$68 \quad$ Id. at $892,894-95$.
$69 \quad 305$ F.3d $684\left(7^{\text {th }}\right.$ Cir. 2002). 
constitute an undue burden. ${ }^{70}$ Under the Indiana law, women had to wait at least 24-hours after receiving information regarding the risks of the abortion procedure, thus necessitating two visits to the abortion provider. The lower court enjoined this provision on the basis of empirical studies conducted in Mississippi and Utah that indicated that the higher costs it imposed would reduce the number of abortions performed in those states by $10 \%$ to $13 \% .^{71}$ Yet, as pointed out by the Seventh Circuit, no research was available regarding the effect that the present requirement would have in Indiana and the researchers had not compared the experience of Mississippi and Utah to Indiana. ${ }^{72}$ At the same time, however, depending on how the legal question was defined, the research might not have to apply specifically to Indiana at all for the Indiana law to be invalidated on the basis of that research. In other cases, the Court had employed a national scope for determining when abortion regulations constituted undue burdens. In Casey itself, as noted above, the Court struck down the spousal notification provision based on general research and did not inquire regarding state-wide experience under the challenged Pennsylvania law. Similarly, in Stenberg v. Carhart ${ }^{73}$ the Court used a national lens to view the pertinent facts when it invalidated a Nebraska law that prohibited the use of "intact dilation and extraction," or what critics have dubbed "partial-birth abortion.",74 In subsequent litigation over this issue, in particular involving congressional legislation on the subject, courts have routinely considered the relevant level of analysis to be at the review-fact stage. ${ }^{75}$

70 A Woman's Choice East Side Women's Clinic v. Newman, 132 F.Supp.2d 1150, 1151 (S.D.Ind. 2001).

$\begin{array}{ll}71 & \text { Id. at } 1173 . \\ 72 & 305 \text { F.3d at } 689 . \\ 73 & 530 \text { U.S. } 914(2000) . \\ 74 & I d . \text { at } 921 .\end{array}$

75 See Hope Clinic v. Ryan, 195 F.3d 857, 884 (7th Cir. 1999) (Posner, J., dissenting) ("The health effects of partial birth abortion should indeed be treated as a legislative fact, rather than an adjudicative fact, in order to avoid inconsistent results arising from the reactions of different district judges...to different records."), vacated 530 U.S. 1271 (2000). 
In cases like Casey and Stenberg, the national approach served the strong jurisprudential value of ensuring consistent constitutional outcomes from state to state. ${ }^{76}$ The Newman court explained the Supreme Court's logic:

[C]onstitutionality must be assessed at the level of legislative fact, rather than adjudicative fact determined by more than 650 district judges. Only treating the matter as one of legislative fact produces the nationally uniform approach that Stenberg demands. ${ }^{77}$

The Seventh Circuit, however, after setting forth this sound explication of why the Court framed the relevant facts under the undue burden test as national legislative facts, devoted the lion's share of its opinion to evaluating the applicability of the research to the operation of the challenged provision in Indiana. The court observed that, "because the undue-burden approach does not prescribe a choice between the legislative-fact and adjudicative-fact approaches, we think it appropriate to review the evidence in this record and the inferences that properly may be drawn at the pre-enforcement stage. ${ }^{78}$ Based on this analysis - what essentially constituted a state level review-fact analysis - the Seventh Circuit reversed the district court's ruling:

Indiana is entitled to an opportunity to have its law evaluated in light of experience in Indiana.... [I]t is an abuse of discretion for a district judge to issue a pre-enforcement injunction while the effects of the law (and reasons for those effects) are open to debate. What happened in Mississippi and Utah does not imply that the effects in Indiana are bound to be unconstitutional, so Indiana ... is entitled to put its law into effect and have that law judged by its own consequences. ${ }^{79}$

The logic of the Seventh Circuit's Newman decision is not obvious. If, indeed, Stenberg specifically, and this area of the law more generally, "demands" the application of a "uniform approach," then the "experience in Indiana" is not particularly relevant to the ultimate determination. It may be that the Mississippi and Utah studies were not sufficiently valid or persuasive to conclude that, on a national scale, informed consent provisions like Indiana's
76
Newman, 305 F.3d at 688.
77
Id.
$78 \quad$ Newman, 305 F.3d at 688-89.
$79 I d$. at 693 (emphasis in original). 
unduly burden the abortion right. But that is a very different determination than saying that the research does not apply in Indiana. Indiana's particular experience is largely irrelevant under Casey's and Stenberg's apparent interpretation of the relevant level of factual inquiry.

As already emphasized, the issue of what level of factual inquiry - i.e., adjudicative-, review-, or rule-fact - should be employed in a particular constitutional context is an interpretive matter. Both Casey and Stenberg appear to treat the applicable inquiry under the undue burden standard as a nationally-defined review-fact. It is possible, however, to distinguish the 24-hour waiting provision from the Casy and Stenberg subjects of spousal notification and late-term abortion. Whereas the Casey and Stenberg subjects do not vary from place to place, a 24-hour waiting provision might be more or less burdensome depending on the state in which it operates. Waiting 24 hours might be a very substantial obstacle in Oklahoma or Utah, but not particularly burdensome in Rhode Island or Delaware, because of the respective distances some women might have to travel to obtain abortion services. Regardless, whatever the judgment regarding the level of fact that is relevant under a particular constitutional provision, it should be an explicit part of the constitutional analysis.

Although sorting constitutional facts into their respective categories appears to be somewhat haphazard, certain conclusions can be offered in regard to this process. First of all, the distinction between adjudicative-facts and review- and rule-facts in constitutional cases is clear in theory, if not always in practice. Adjudicative-facts pertain to specific cases and have little or no precedential force, while review- and rule-facts are general in nature and usually have import as a matter of precedent. These general facts will sometimes be relevant to the definition of the constitutional rule itself (i.e., constitutional rule-facts) or, more often, will be relevant when some rule is applied to a set of general facts (i.e., constitutional review-facts). Second, the decision whether the relevant fact under a particular constitutional rule falls into one category or another is an interpretive judgment; and it is a judgment that should always be made explicitly. Under Casey's undue burden standard, as discussed above, the determination whether a 24-hour waiting provision constitutes a "substantial obstacle" could be an adjudicative-fact or a review-fact. 
Indeed, at the review-fact level, the pertinent scope for fact-finding could be national, state-wide, or the respective court's jurisdiction. What measure of fact-finding is ultimately deemed appropriate must depend on the constitutional values at stake. Very different procedural consequences follow depending on the level of fact that courts find to be relevant. These procedural consequences inevitably affect the substantive expression of constitutional rights.

Finally, the choice made regarding what kinds of facts are relevant under a particular constitutional provision will determine the sorts of proof that might be used to find those facts. The type of evidence used to prove adjudicative-facts usually differs markedly from the type of evidence used to prove review-facts and, moreover, the identity of the respective finder of fact changes as well. The next section takes up the matter of how different kinds of constitutional facts might be proven.

\section{Proving Constitutional Facts}

Two basic issues are presented by the question of how constitutional facts are to be proven. The first concerns what sort of proof is allowable, or, to use an evidentiary term, "admissible," to demonstrate that the fact is so or is not so. Terminology from evidence doctrine, however, is misleading, since so much proof of constitutional facts comes to the knowledge of courts outside of the trial process in which rules of evidence preside. The second basic issue involves what decision-rules courts use to resolve conflicting evidence. Again, decision-rules, such as burdens of production and standards of proof, are readily found in ordinary trial procedure, but the highly varied ways in which constitutional facts are employed by courts makes the analogy inexact. Constitutional facts present novel challenges to the traditional procedural framework, since they sometimes fit it, sometimes do not, and sometimes fit it and do not fit it at the same time. In many cases, for instance, the same constitutional fact will be the subject of proof admitted at trial and proof introduced in an amicus brief. Evaluation criteria in constitutional cases, therefore, might parallel those employed in evidence codes, but they also must be applicable more generally to the factual determinations endemic to the Constitution. In addition, although allocating burdens of proof is inherent to all fact-finding, the Court has 
historically viewed facts categorically in its constitutional analysis, as either true or not true, a perspective wholly at odds with modern views of empiricism. This section considers both the question of evidentiary standards and standards of proof. Once again, the division of facts into the categories of rule-, review-, and adjudicative-facts assists in the resolution of these issues.

Yet, before moving on to examine the sources and burdens of proof for the different types of constitutional facts, two issues bear emphasis here, since they apply to the establishment of all three types of constitutional facts. The first, mentioned in the previous sections, is that what sorts of facts are relevant in particular constitutional contexts is a matter of constitutional interpretation. Constitutional values must be used to determine whether undue burdens are measured nationally, on a case-by-case basis, or somewhere in-between, whether claims of discrimination under the Eighth Amendment must be specific to the case or can be systemic, or whether the effects of segregation are to be measured nationally or school-by-school. The second issue is related to this proposition, in that once the sort of fact having constitutional relevance has been established, courts must also determine, as a constitutional matter, the kinds of proof that might be adequate to prove or disprove the fact. In social scientific terms, this issue concerns what is referred to as the "operational definition" of the concept having constitutional relevance. Legal notions such as competence, intelligence, and cruel and unusual, must be defined concretely so that they can be measured for adjudicatory purposes. ${ }^{80}$ The issue of what must be proven in order to meet the constitutional inquiry is a subject of law and a function of constitutional interpretation.

80 Operational definitions permit the inter-subjective testing of hypotheses, in that they give different researchers (or judges) a concrete idea what abstract concepts mean. A study on jury deliberations, for example, might consider a host of outcome variables, operationally defined as, say, verdicts (measured by jury awards in dollars), length of time of deliberations (measured in minutes), juror satisfaction (measured by juror responses to a questionnaire), and so on. The basic idea of an operational definition is endemic to all science. For example, meteorologists might measure temperature by use of a thermometer or by "wind-chill." Windchill combines thermometer readings with wind speed and takes into account physiological factors, such as heat loss from the body (i.e., modern heat transfer theory). For an excellent discussion of wind chill, including conversion charts, see http://www.weather.gov/om/windchill/index.shtml. 
In Atkins v. Virginia, for example, the Court held that executions of mentally retarded criminals constituted cruel and unusual punishment prohibited by the Eighth Amendment. Although the Court did not specifically define what qualifies as valid proof of mental retardation, it is clear that this will be a central point of contention in subsequent cases. ${ }^{81}$ The question of whether an individual capital defendant is mentally retarded for purposes of an Atkinsanalysis and thereby categorically excluded from the death penalty - is a constitutional fact. But how mental retardation is to be operationally defined must be resolved as a matter of law. This will prove to be difficult, however, since the issue of where to draw a categorical line on I.Q. that distinguishes low intelligence from retardation is not a straightforward exercise. Ideally, the line between an un-executable mentally-retarded criminal and an executable low-intelligence criminal should be drawn on the basis of the reasons the AtkinsCourt gave for holding that it was cruel and unusual to execute mentally retarded murderers in the first place. According to Justice Stevens' opinion, these reasons include, among others, that the twin purposes of deterrence and retribution do not apply to the mentally deficient in the same way that they apply to those without similar intellectual deficiencies. Unfortunately, research provides little guidance on just how mentally deficient a person would have to be for deterrence and retribution not to apply to him or her. $^{82}$

The question, therefore, of how the category of "mental retardation" is to be operationally defined for Atkinspurposes is a constitutional rule, with all of the ambiguity and normative considerations that attend these sorts of determinations. ${ }^{83}$ Rule-facts are likely to be relevant to

81 See, e.g., In re Bowling, 422 F.3d 434, 436-37 (6 ${ }^{\text {th }}$ Cir. 2005) ("Atkins did not set forth a definitive rule or procedure for the courts to follow in determining when an offender is mentally retarded such that his or her execution would violate the Eighth Amendment. Instead, Atkins reserved for the states "the task of developing appropriate ways to enforce the constitutional restriction" upon the execution of sentences.") (quoting Roper536 U.S. at 317)).

$82 \quad$ See Atkins, 536 U.S. 304, 350 (Scalia, J., dissenting) ("[W]hat scientific analysis can possibly show that a mildly retarded individual who commits an exquisite torture-killing is 'no more culpable' than the 'average' murder in a hold-up-gone-wrong or a domestic dispute?').

$83 \quad$ See infra Section II.1.a. 
the delineation of this category and together with normative considerations can contribute to the construction of a practicable framework. Once this category is defined, however, proof regarding whether a particular capital defendant is "mentally retarded" is a constitutional adjudicative-fact.

A parallel process must occur with constitutional review-facts, as evidenced by Roper $v$. Simmons. Following fast upon Atkins, the Roper Court held that executing criminals who committed their crimes when they were sixteen or seventeen was unconstitutional. Roper relied on a similar form of analysis to Atkins, in that the Court found that minors were less responsible for their actions and less likely to be deterred by the death penalty than adults. Rather than require individual competency assessments, as was essentially the case in Atkins, the Court held that the rule applied to all minors, even though some might have reasoning capacities equal to those of adults. In reaching its conclusion that executing those who committed their crimes as minors was unconstitutional, the Court cited three factual conclusions that supported the decision: surveys of American attitudes toward executing minors, the psychological and physiological developmental differences between minors and adults, and surveys of international practices on the subject. Each of these grounds raises constitutional review-facts, the proof of which is discussed in this section. But the kinds of proof that are adequate to prove these facts is an issue that must be determined as a matter of law. For instance, under the Eighth Amendment, the Court has repeatedly stated that Americans' attitudes toward the death penalty is a relevant consideration. The Court, however, operationally defines this factual issue as a matter of state legislative practice, as opposed to, say, popular surveys of voters or Americans more generally. ${ }^{84}$ Thus, that contemporary views of the death penalty are relevant and that these views are measured largely by virtue of state legislative practice, are legal considerations determined according to the Court's understanding of the Constitution's meaning. Once determined to be constitutionally relevant, surveys of state constitutional practice (or international practices, or the developmental capacities of minors) become constitutional review-facts that must be found

$84 \quad$ See Penry v. Lynaugh, 492 U.S. 302, 311 (1989) (When determining whether a punishment is "cruel and unusual" under the evolving standards of decency embraced by the Eighth Amendment, the Court has emphasized that state legislation is the "clearest and most reliable objective evidence of contemporary values.") 
according to particular rules of procedure. This section examines the procedures that might be appropriate for finding constitutional facts, depending on the sort of fact that has been accorded constitutional significance.

\section{Proving Constitutional Rule-Facts}

Rule-facts are typically the grandest and most amorphous facts found in constitutional cases. The two most common are historical facts associated with original intent and sociological facts associated with structural issues surrounding the operation of the Constitution. Both kinds are replete with uncertainty, much of it associated with the difficulty of studying these respective subjects. Evidentiary standards and decision-rules must be responsive to the nature of the proof available. This means that traditional notions surrounding evidence and standards of proof are largely inapposite in the case of constitutional rule-facts. Rule-facts tend to be as much a product of aspiration as they are deduced from evidence.

\section{a. Sources of Proof}

Rule-facts are a component of the interpretive process of determining the meaning of specific provisions of the Constitution. They are thus part of the law making process. As a consequence, rule-facts are only tangentially a function of the adversarial process. Although the parties are charged with the responsibility to inform courts about the applicable law, including the authorities that support that law, courts independently determine the law's content. Courts are not restricted to the parties' views on the Constitution's meaning, nor are they bound to the authorities presented by the parties for determining that meaning. Just as a judge might retire to the library to research a line of cases, he or she might consult "The Federalist" when considering what foundational principles underlie the Supremacy Clause.

Rule-facts, therefore, generally do not come to courts' attention through expert witnesses or testimony at trial. On occasion, perhaps, a trial court might request testimony on a fact that is relevant to the definition of a rule, but this is likely to be relatively rare. More often, factually- 
based supporting arguments for original intent or constitutional structure will be presented in briefs or memoranda based on independent research published in articles or books. As noted, judges might also independently consult these sources in an effort to frame or shape doctrine. Indeed, a goodly amount of a judge's extra-judicial reading might involve histories that could influence his or her perspectives on constitutional law. A judge who reads a biography of Alexander Hamilton or a history of the New Deal Court might very well apply this new found knowledge to his or her constitutional cases.

As a practical matter, rule-facts are complexly intertwined with logical and normative arguments. It will often be hard to say where the empirical argument ends and the normative argument begins. For example, in New York Times $v$. Sullivan, ${ }^{85}$ the Court adopted the "actual malice" standard for libel actions brought by public officials against critics of their official actions. When applied, this rule requires proof by adjudicative facts, since actual malice requires a showing "that the statement was made with ... knowledge that it was false or with reckless disregard of whether it was false or not." ${ }^{, 86}$ But the New York Times rule is, itself, based on a combination of normative propositions and factual predicates.

Justice Brennan, writing for the Court in New York Times, relied on both historical facts and sociological facts to support the new defamation standard. He argued, for example, that the libel standard applied by the lower court was similar to the Sedition Act of 1798, a law invalidated "in the court of history" due to the restraints it "imposed upon criticism of government and public officials." 87 Additionally, Brennan asserted, because "erroneous statement is inevitable in free debate," even false statements must "be protected if the freedoms of expression are to have the 'breathing space' that they 'need ... to survive.", 88 Brennan stated
$85 \quad 376$ U.S. 254 (1964).
$86 \quad$ Id. at $279-80$.
$87 \quad$ Id. at 276.
88 Id. at 271-72 (quoting NAACP v. Button, 371 U.S. 415, 433 (1963)). 
that the Alabama rule could not be "saved by its allowance of the defense of truth." This rule, he observed, leads to "self-censorship." "[W]ould-be critics of official conduct may be deterred from voicing their criticism, even though it is believed to be true and even though it is in fact true, because of doubt whether it can be proved in court or fear of the expense of having to do so." 89 The Alabama libel rule, the Court concluded, "dampens the vigor and limits the variety of public debate." 90 The Free Speech Clause, then, assumes its meaning in part from the historical lessons surrounding attempts to suppress expression and the effects of particular rules on human behavior.

There are two particularly noteworthy aspects of constitutional rule-facts, as illustrated by Justice Brennan's opinion in New York Times. The first is, as noted, the seamless character of the argument between, on the one hand, statements regarding the normative values inherent in the First Amendment - free discourse, debate and dissent - and, on the other hand, the factual arguments regarding the history of the Sedition Act or Brennan's account of the psychology of civil libel law and its potential to chill speech. In terms of evaluating which premises are doing the work, one premise cannot be disentangled easily from the others. As is often true in this context, the factual arguments in New York Times are interwoven into the textual and normative ones.

Another characteristic of rule-facts evidenced in New York Times is the virtual total lack of supporting authorities for these assertions. Because of their generally abstract and highly complex nature, judges generally feel less compulsion to cite supporting authorities for rule-facts than they do for the other kinds of constitutional facts. Historical facts, particularly those with constitutional relevance, often seem to assume mythical qualities. Many become part of the lore of constitutional doctrine, much as George Washington's cherry tree is an abiding fiction taught to generations of school children. Arguments for a strong reading of the Second Amendment, for example, seem to have as much to do with late twentieth-century Hollywood as late eighteenth-

$89 \quad I d$. at $278-79$.

$90 \quad I d$. 
century Philadelphia. ${ }^{91}$

\section{b. Allocating Burdens of Proof}

Factual claims surrounding "original intent" occupy the largest niche of constitutional rule-facts. But the task of reliably identifying original intent is beset by several basic challenges, some associated with the strain of stating the constitutionally relevant inquiry and others concerned with the difficulty of fact-investigation in historical analysis. As regards the former, courts and commentators have never adequately defined the specific issue in original intent that is the source of constitutional meaning. ${ }^{92}$ Indeed, even the question of the initial relevance of original intent has been challenged. ${ }^{93}$ But assuming its relevance, what inquiry is constitutionally mandated? Is it the drafters' intent?, the ratifiers' intent?, and what degree of agreement among the possible "intenders" is necessary to determine a specific intent?" Complicating matters substantially is the latter challenge, that history as a discipline is rarely able to provide definitive proof and is very susceptible to the biases of the age in which it is done. Although historians have many powerful methodological tools, the picture they provide usually offers little more than a dim perception of a world shrouded in the mists of time.

Similarly, sociological or political science explorations into the structural operation of the Constitution are assailed by the complexity of the subject. Consider, for example, one of the perennial structural issues presented by the American Constitution, the question whether small republics (i.e., the states) are more likely to be protective of liberty than large republics (i.e., the

91 See Whose Right to Bear Arms Did the SECOnd Amendment Protect? (Saul Cornell, ed., 2000).

92 See Henry P. Monaghan, Our Perfect Constitution, 56 N.Y.U. L. REV. 353, 360 (1981).

93 See William Brennan, My Encounters with the Constitution, JUDGES J., Summer 1987, at 7, 10 .

$94 \quad$ See Powell, supra note XX, at 888. 
national government). ${ }^{95}$ This debate divided Jefferson and Madison in 1787, the Nation in 1861, and continues to this day to affect both constitutional doctrine and popular debate. Debates over states' rights have for some time failed to seriously evaluate Montesquieu's assertion that "[i]t is natural to a republic to have only a small territory, otherwise it cannot long subsist." 96 Alexander Hamilton deftly refuted Montesquieu's relevance to the constitutional debate, observing, “[w]hen Montesquieu recommends a small extent for republics, the standards he had in view were of dimensions far short of the limits of almost every one of these States."97 Yet, to this day, and based on neither reason nor experience, the perspective associated with Montesquieu remains a core stricture of constitutional faith. Presumably, there is a fact of the matter, but it is likely one that is highly complex and contextual, and the tools of social science are unlikely ever to give us a definitive answer. Instead, the facts are known sufficiently enough only to give the opposing sides enough ammunition to sustain an argument. The choice between traditional Federalist beliefs in the virtues of a large republic and traditional Anti-Federalist beliefs in States' rights largely depends on differing policy agendas rather than disagreements over natural philosophy or political science.

For the most part, the sorts of facts that underlie constitutional rules are as much articles of faith as they are matters of scientific investigation. The concept of burdens of proof do not readily apply to such fact-finding, since there is little, if any, quantitative quality to their discovery. The most that can be said is that these facts are known with more or less confidence, but the ranges of such confidence are likely to be fairly wide. Moreover, as noted above, rulefacts are typically used in conjunction with other authorities, such as textual interpretation and

95

Martin S. Flaherty, History “Lite” in Modern American Constitutionalism, 95 Colum. L. Rev. 523, 571 (1995); Symposium, The Republican Civil Tradition: Beyond the Republican Revival 97 YALE L.J. 1539, 1558 (1988); see generally, James S. Liebman \& Brandon L. Garrett, Madisonian Equal Protection, 104 CoLUM. L. REV. 837 (2004).

96 Bernard BAILyn, ED., The Debate On the Constitution, Volume 1, 170-171 (1990).

97 Alexander Hamilton, John Jay, and James Madison, The Federalist, no. 9, 50 (Norwalk, Conn.: Easton Press, 1979). 
precedent, and thus rarely have independent significance for the definition of particular doctrine. It would make little more sense to apply burdens of proof to historical facts than it would to apply such decision-rules to the holdings of precedent. Defining the Constitution is, at bottom, a rhetorical exercise, and although facts are often employed in the process, rule-facts are a constituent part of the process of setting the Constitution's meaning and cannot be well understood or effectively evaluated outside of the interpretive enterprise.

\section{Proving Constitutional Review-Facts}

Review-facts become relevant under constitutionally-based rules or standards. They share qualities of both rule-facts and adjudicative-facts. Like the former, they transcend individual cases and, once found, have precedential effect. Like the latter, however, they typically can be operationally defined ${ }^{98}$ and subject to substantial, if not definitive, proof. Unlike rule-facts, review-facts can be taken seriously in constitutional adjudication because they are defined largely independently of normative considerations. With review-facts, there is more likely to be a fact-of-the-matter that can be studied by multiple researchers, whose terms can be operationally defined, and which is amenable to refutation. Given their complexity, the role of evidentiary standards and standards of proof are especially important when review-facts are in dispute.

\section{a. Sources of Proof}

Courts become aware of review-facts in a myriad of ways. Proof of review-facts is introduced through expert testimony, in the briefs and memoranda of the parties and amici, and through independent judicial research. Immediately apparent, given the wide variety of pathways, is the range of standards that might be employed in the reception of proof of these facts. At trial, evidence regarding review-facts must overcome the fairly substantial threshold provided by rules of admissibility, typically those involving expert testimony. On appeal, in

\footnotetext{
See supra notes XX-XX, and accompanying text for a discussion of "operational definitions."
} 
contrast, courts routinely accept amicus briefs chock-full of factual assertions from interested parties who might, or might not, have expertise on the subject. Relatedly, constitutional reviewfacts are introduced at every level of court. Historically, there has been no practice or tradition that review-facts be introduced at trial and survive the rigors of the adversarial process. Indeed, the celebrated Brandeis Brief is an example of the extra-evidentiary admission of constitutional review-facts. In Muller v. Oregon, ${ }^{99}$ the sociological arguments Brandeis used to justify the Oregon law were presented first on appeal. A certain degree of confusion, therefore, reigns in constitutional cases when it comes to proof of review-facts.

Despite the somewhat chaotic situation surrounding review-facts, the state of affairs is nothing like the free-for-all that occurs with rule-facts. Moreover, review-facts merit more serious and systematic attention than do rule-facts. Rule-facts tend to be amorphous and abstract, and rarely do the heavy lifting in constitutional interpretation. Review-facts, in contrast, are more concrete, more likely to be amenable to rigorous empirical research, and more often taken seriously in constitutional adjudication. Constitutional cases are replete with review facts. In Barnes v. Glen Theatre ${ }^{100}$ and City of Erie v. Pap's $A M,{ }^{101}$ the Court accepted the proposition that nude dancing establishments lead to increased crime, including prostitution, drug abuse, and assaults. Explicitly in Barefoot v. Estelle ${ }^{102}$ and United States v. Salerno, ${ }^{103}$ and implicitly in Kansas v. Hendricks ${ }^{104}$ and Kansas v. Crane, ${ }^{105}$ the Court rejected the proposition that psychiatrists and psychologists are unable to adequately predict whether a person will be violent
99208 U.S. 412 (1908).
$100 \quad 501$ U.S. 560 (1991).
$101 \quad 529$ U.S. 277, 290-91 (2000).
102463 U.S. 880, 896 (1983).
$103 \quad 481$ U.S. 739, 751-52 (1987).
$104 \quad 521$ U.S. 346, 358-60 (1997).
105534 U.S. 407, 411-13 (2002). 
in the future. In Ashcroft v. Free Speech Coalition, ${ }^{106}$ the Court refused to invalidate a congressional statute regulating virtual child pornography because of the lack of empirical evidence that these materials caused substantial societal harms. ${ }^{107}$ And the list of such cases involving review-facts goes on almost without end. Given their abundance, one might have thought that some procedural guidelines or evaluative guideposts would apply to proof of constitutional review-facts. As of yet, however, there are none.

Less so than rule-facts, and more so than adjudicative-facts, review-facts implicate basic constitutional values and effectively establish constitutional boundaries. In Grutter v. Bollinger ${ }^{108}$ for example, the Court said that the strict scrutiny test applied to the affirmative action program adopted by the University of Michigan's School of Law. This test provides "that [racial] classifications are constitutional only if they are narrowly tailored to further compelling governmental interests." ${ }^{109}$ Under this test, courts review both the means and the ends of programs classifying by race, and both involve inquiries regarding constitutional facts. The Court, therefore, ostensibly analyzed whether Michigan's objective was sufficiently compelling and whether the means chosen to effectuate that objective were narrowly tailored.

The compelling government interest, the Court stated, was the single justification of "obtaining "the educational benefits that flow from a diverse student body." 110 Although the Court deferred to the school's "educational judgment that such diversity is essential to its educational mission," "111 it summarized the basis for the factual conclusion that educational

\footnotetext{
$106 \quad 535$ U.S. 564 (2002).

$107 \quad$ Id. at $253-54$

108539 U.S. $306(2003)$.

$109 \quad I d$. at 326.

110 Id. at 327 (quoting Brief for Respondents Bollinger et al. i.).

111 Id. at 328; see discussion supra notes X-X and accompanying test, regarding the standard of proof for this factual inquiry.
} 
benefits flow from a diverse student body. The district court, for instance, found that "“crossracial understanding' helps to break down racial stereotypes, and 'enables [students] to better understand persons of different races." "112 The benefits of diversity mean that " classroom discussion is livelier, more spirited, and simply more enlightening and interesting" when the students have "the greatest possible variety of backgrounds.",113 The Court insisted that the educational benefits of diversity "are not theoretical but real." 114 The Court supported this assertion by observing that, "[i]n addition to the expert studies and reports entered into evidence at trial, numerous studies show that student body diversity promotes learning outcomes, and 'better prepares students for an increasingly diverse workforce and society, and better prepares them as professionals." 115 The Court cited an assortment of amicus briefs and scholarly books to buttress this conclusion. ${ }^{116}$

The GrutterCourt relied on a variety of authorities to support its finding that Michigan reasonably believed that racial diversity promoted educational benefits. ${ }^{117}$ In Grutter these authorities were introduced through evidence adduced at trial, amicus briefs, and scholarly materials. Presumably, however, while the expert evidence introduced at trial survived some

\footnotetext{
$112 \quad I d$. at 330.

$113 \quad$ Id

$114 \quad I d$.

115 Id. (quoting Brief for American Educational Research Association et al. as Amici Curiae 3).

$116 \quad I d$.

117 See also Planned Parenthood Fed'n of Am. v. Ashcroft, 320 F. Supp. 2d 957 (N.D. Cal. 2004) (granting a permanent injunction to enjoin enforcement of the Partial-Birth Abortion Ban Act of 2003 after relying on testimony from eight expert witnesses and an amicus brief submitted by the California Medical Association and the San Francisco Medical Society). The Ninth Circuit affirmed the district court's opinion in Planned Parenthood Fed'n of Am. v. Gonzales, 2006 WL 229900, at * 13, 20 (9th Cir. filed Jan. 31, 2006) (affirming the district court's decision after relying, in part, on amici, including a brief by the California Medical Association).
} 
threshold assessment of validity, the other sources of data, so far as the opinion indicates, received no similar kind of threshold evaluation. The question naturally arises, therefore, whether evidence of constitutional review-facts should be assessed for validity and, if so, by what standards this should be done.

In federal courts, expert evidence is preliminarily assessed under Rule 702 and the Court's decision in Daubert v. Merrell Dow Pharmaceuticals, Inc. ${ }^{118}$ Daubert held that trial courts are gatekeepers and must be persuaded by a preponderance of the evidence that the basis for expert opinion is reliable and valid before it can be admitted. As a procedural matter, however, it would be impractical to apply Daubert to proof of constitutional review-facts. Despite some justices' lament that constitutional facts should undergo the scrutiny of the adversarial process, ${ }^{119}$ this is an unrealistic and unhelpful perspective. First of all, because constitutional review-facts transcend any single litigation, and thus have precedential import, the development of a factual record cannot be left to the parties. An attorney's failure to adequately develop the factual record in an ordinary dispute only affects his or her client's matter. Such a failure in constitutional litigation potentially affects a multitude of cases. The Court cannot be limited to the record before it when determining constitutional review-facts. If amici were not readily available to supply evidence regarding review-facts, the Court would be obligated to conduct its own independent research. In this sense, questions regarding review-facts bear some resemblance to questions surrounding the correct legal standard. Just as no court would defer to the parties to say what the law is, no court should rely on the parties exclusively to say what the review-facts are.

118 509 U.S. 579 (1993).

119 See, e.g., Kyles v. Whitley, 514 U.S. 419, 457 (1995) (Scalia, J., dissenting) (criticizing the majority for "render[ing] new findings of fact and judgments of credibility appropriate to a trial court of original jurisdiction"); Iron Arrow Honor Soc. v. Heckler, 464 U.S. 67, 73 (1983) (Brennan, J., dissenting) (writing that "the issue of mootness [was] sufficiently dependent on uncertain factual issues," after the majority weighed the significance of a document on its own in finding the case moot). 
Although Daubert as a rule of evidence does not ordinarily apply to proof of constitutional review-facts, the core principles of that decision can offer some guidance to assessing the methodological bases of such proof. In short, Daubert stands for the proposition that the probative value of expert evidence is proportionate to the quality and quantity of the data that support it. In the case of scientific evidence, for instance, Daubert held that expert opinions based on research that was inadequately tested, that had high or unknown error rates, that had not been subjected to peer review or been published, and that had failed to gain general acceptance in its particular field, was likely to have little validity and thus low evidentiary reliability. But the core principle of Daubert extends to all fact-based experts, not just scientists. Under Daubert and subsequent cases, all experts must show that their opinions are based on "good grounds." 120 The mere assertion of "years of experience," or what the Court has referred to as the "ipse dixit" of the expert, ${ }^{121}$ is not alone sufficient to verify expert opinion.

Daubert largely incorporates the critical perspective associated with the methods of scientific investigation. This approach should inform judicial reception of evidence regarding constitutional review-facts. Judges should measure empirical claims in accordance with the methods on which these claims are based. Invariably, knowledge about the empirical world will be known with greater or lesser confidence. And the more complex the phenomenon, the more difficult it will be to study. Indeed, often, if not more often than not, the complex phenomena relevant in constitutional cases will be largely beyond the methodological abilities of scientists. When this is so, the normative principles of the Constitution must be consulted in order to allocate the risk of error. In short, the Constitution establishes rules of decision for fact-based inquiries. For example, the constitutionality of a law prohibiting virtual child pornography depends, in part, on the factual question of whether such materials contribute to violence against children, a subject on which there is little evidence. In Ashcroft v. Free Speech Coalition, ${ }^{122}$ the

$120 \quad$ Kumho Tire Co. v. Carmichael, 526 U.S. 137, 157 (1999).

121 General Electric Co. v. Joiner, 522 U.S. 136, 146 (1997).

$122 \quad 535$ U.S. 234 (2002) 
Court invalidated the statute proscribing virtual child pornography on the basis that the government had failed to adduce evidence supporting its empirical claims. ${ }^{123}$ If the government had produced such evidence, it should have been evaluated under a Daubert-like inquiry. Such inquiries must be guided by burdens of proof that correspond to the constitutional values at stake. As was true in Free Speech Coalition, if no evidence is forthcoming, the party that bears the burden of proof loses.

\section{b. Allocating Burdens of Proof}

The basic problem inherent in the court's current approach to finding constitutional review-facts is itsad hoc nature. Although, as noted, the Court oftentimes speaks in terms of "rational basis review" and "strict scrutiny," it virtually never specifies what burdens of proof apply to the fact-finding that must occur under these standards. Constitutional-review facts and constitutional-adjudicative facts, by definition, are relevant under particular constitutional rules. Part of the explication of any constitutional rule should include a statement of which party - the challenger or the State - has the burden of proof and at what level of proof that burden must be met.

Given the enormity of the task and the limited space available here, I can only introduce the idea of incorporating evidentiary burdens of proof into constitutional adjudication. ${ }^{124}$ But the core insight is clear and should be relatively easily implemented. Consider, for example, the Court's "undue burden" standard, discussed above, which was first set forth in its modern form by a plurality of the Court in Planned Parenthood v. Casey ${ }^{125}$ and later applied by a majority in Stenberg v. Carhart. Casey described the undue burden test as follows:

Numerous forms of state regulation might have the incidental effect of increasing the cost or decreasing the availability of medical care, whether for abortion or any other medical

$123 \quad$ Id. at $253-54$.

124 [Identifying footnote removed]

$125 \quad 505$ U.S. 833 (1992). 
procedure. The fact that a law which serves a valid purpose, one not designed to strike at the right itself, has the incidental effect of making it more difficult or more expensive to procure an abortion cannot be enough to invalidate it. Only where state regulation imposes an undue burden on a woman's ability to make this decision does the power of the state reach into the heart of the liberty protected by the Due Process Clause. ${ }^{126}$

According to the opinion jointly authored by Justices O'Connor, Kennedy, and Souter, “[a] finding of an undue burden is a shorthand for the conclusion that a state regulation has the purpose or effect of placing a substantial obstacle in the path of a woman seeking an abortion of a nonviable fetus."127 The undue burden test as formulated, and as applied by the joint opinion in Casey, is primarily fact-based. In effect, the undue burden test strikes a balance between individual liberty and government interests in the definition of the rule, but fails to explain how that rule should be applied in concrete cases.

Two provisions of the Pennsylvania law illustrate the confusion surrounding the application of the undue burden test. The Pennsylvania law, among other things, imposed a 24hour waiting period and contained a spousal notification provision. ${ }^{128}$ The joint opinion upheld the former and invalidated the latter. Yet, it appears that substantial proof existed indicating that the two provisions were burdensome, thus casting doubt on the constitutionality of both of them. Indeed, the district court found that the 24-hour waiting provision "increas[ed] the cost and risk of abortions"129 and was "particularly burdensome," 130 and, additionally, found that spousal notification would significantly burden the basic right of reproductive choice among some women.
126
Id. at 874 .
127
Id. at 877 .
128
Casey, 505 U.S. at 844-45.
129 Id. at 886 (quoting Planned Parenthood v. Casey, 744 F.Supp. 1323, 1378

(E.D.Pa. 1990)).

Id. 
The joint opinion in Casey concluded that the spousal notification provision was unduly burdensome but that the evidence did not support a similar conclusion regarding the 24-hour waiting requirement. But the opinion failed to explain its reasons for believing that one provision was unduly burdensome while the other was not. As regards the 24-hour waiting provision, the joint opinion simply stated, "on the record before us, ... we are not convinced that the 24-hour waiting period constitutes an undue burden."131 In contrast, the joint opinion adopted the factual findings of the district court in striking down the spousal notification provision. Indeed, the joint opinion went beyond the findings of the district court and cited research studies that were not in the record. ${ }^{132}$ The joint opinion concluded that " $[\mathrm{t}] \mathrm{he}$ spousal notification requirement ... does not merely make abortions a little more difficult or expensive to obtain; for many women, it will impose a substantial obstacle.",133

A large part of the ambiguity associated with constitutional adjudication stems from the Court's refusal to recognize the empirical component of constitutional review-facts and its failure to allocate responsibility for demonstrating review-facts having constitutional import. Under the Commerce Clause, for instance, the Court has long insisted that Congress need not demonstrate that a challenged regulation "substantially affects interstate commerce," though it has suggested that such proof might be of assistance to the Court's determination. ${ }^{134}$ Recent cases, however, indicate a large measure of ambiguity over whether Congress bears any burden of proof in these cases, or, if so, what the nature of that burden is. In United States v. Lopez, ${ }^{135}$ the Court stated
$131 \quad$ Id. at 887.
132 Id. at 992 n.6 (Scalia, J., dissenting).
133 Id. at 893-94.

134 See Katzenbach v. McClung, 379 U.S. 294, 299 (1964) (Court noted that, "while no formal findings were made [by Congress], which of course is not necessary, it is well that we make mention of the testimony to determine whether the Act is a reasonable and appropriate means [to regulate commerce]."); Perez v. United States, 402 U.S. 146, 156 (1971) ("We have mentioned [the] economic, financial, and social setting of the problem as revealed to Congress. We do so not to infer that Congress need make particularized findings in order to legislate."). 
that it agreed "that Congress normally is not required to make formal findings as to the substantial burdens that an activity has on interstate commerce." ${ }^{136}$ The Court failed to say what circumstances might not qualify as "normal." Moreover, the Court stated cryptically that, "to the extent that congressional findings would enable us to evaluate the legislative judgment that the activity in question substantially affected interstate commerce, even though no substantial effect was visible to the naked eye, they are lacking [here]."137 Justice Breyer, in dissent, offered a factual basis for Congress' judgment that guns in school zones substantially affect interstate commerce. It is unclear, however, whether if Congress had forwarded the justification identified by Breyer it would have made any difference. More to the point, it is unclear what standard of proof applies in Commerce Clause cases after Lopez. ${ }^{138}$

\section{Proving Constitutional Adjudicative-Facts}

Adjudicative facts are, in many respects, the most anomalous sort of facts in constitutional cases. On the one hand, they are seemingly the most manageable kinds of facts. They are readily recognized, since they are case-specific, and ostensibly are subject to all of the ordinary rules of procedure and evidence. Also, because they are case-specific, they do not appear to have many precedential consequences. On the other hand, they can be difficult to manage and can, in fact, be complex and extraordinary. Most difficult is the initial question whether the relevant inquiry should be at the adjudicative-fact or legislative-fact level (whether review- or rule-fact). For example, in New York v. Ferber, ${ }^{139}$ the Court held that the deleterious
136
Id. at 560 .
137
Id.

138 Compare United States v. Morrison, 529 U.S. 598 (2000) (rejecting extensive congressional findings that violence against women, in the aggregate, substantially affects interstate commerce) with Gonzales v. Raich, 125 S.Ct. 2195 (2005) (stating that the test is not whether the questioned activity, in the aggregate, actually substantially affects interstate commerce, but whether there exists a "rational basis" for Congress to conclude that there is such a nexus). 
consequences that were suffered by children who appeared in child pornography were sufficient to justify the proscription of this entire class of speech. Although not described in such terms, the physical and psychological consequences of child pornography for the children involved in it were treated as constitutional review-facts in Ferber. The Ferber Court cited "the legislative judgment that the use of children as subjects of pornographic materials is harmful to the physiological, emotional, and mental health of the [child]. ${ }^{, 140}$ In contrast, and in dissent, Justice Brennan argued that the appropriate level of analysis should be case-specific, for allowing prohibitions of all child pornography swept too broadly and affected materials having scientific, literary, or artistic value. Justice Brennan preferred the use of a Miller styled test, which would have made the relevant constitutional fact adjudicative, as is the case for materials alleged to be obscene.

Although constitutional adjudicative-facts have no formal effect as precedent, they are nonetheless likely to reverberate throughout subsequent cases. They often establish constitutional boundaries and effectively serve as "cases-in-point" for the limits or allowances of constitutional doctrine. In addition, in the individual cases in which they are found, they invariably affect constitutional rights and values. As a consequence of this greater constitutional role, constitutional adjudicative-facts are generally understood as raising mixed questions of fact and law and thus garner substantially more judicial attention than run-of-the-mill adjudicativefacts. $^{141}$

\section{a. Sources of Proof}

Adjudicative-facts, because they are case-specific, normally are proven by the testimony of lay or expert witnesses. There is little of significant controversy surrounding these facts, since

Id. at 758 .

141 See Bose Corp. v. Consumers Union of United States, 466 U.S. 485 (1984); see generally Monaghan, supra note XX, at 238 ("We commonly assume that there is something distinctive about judicial review of the adjudicative facts decisive of any constitutional claim."). 
courts are usually content to allow ordinary rules of evidence and procedure to apply to them. When disputed in court, rules of evidence apply to proffered testimony, writings, or other materials. There are, however, at least two special situations that arise fairly commonly concerning constitutional adjudicative-facts that merit some attention. First, rules of evidence are sometimes challenged on the basis that they violate the Constitution. And second, the Constitution might be interpreted to require certain kinds of proof, such as expert testimony over that of lay testimony.

Like all statutes, rules of evidence must conform to constitutional guarantees. Evidence codes apply to all adjudicative facts, so there is an Escher-like quality to factual challenges to the constitutionality of a rule of evidence. Consider, for example, the cases of Rock v. Arkansas ${ }^{142}$ and United States v. Scheffer. ${ }^{143}$ These two cases raised similar Sixth Amendment issues, but were resolved quite differently, both as a substantive matter and in regard to the Court's treatment of the constitutional facts implicated in the cases. In Scheffer, the defendant claimed that the United States military's per se rule excluding polygraph evidence violated his Sixth Amendment right to present a defense. ${ }^{144}$ The defendant in Scheffer relied on Rock, in which the Court had stated that rules of evidence "may not be arbitrary or disproportionate to the purposes they are designed to serve." 145 Based on this admonition, the Rock Court invalidated the Arkansas per se rule prohibiting the admission of hypnotically refreshed testimony. The Court concluded that a "State's legitimate interest in barring unreliable evidence does not extend to per se exclusions that may be reliable in an individual case." 146 The Scheffer Court, however, found the per se rule excluding polygraphs not to be arbitrary, since it was designed to exclude unreliable evidence. The Court found that "there is simply no consensus that polygraph evidence

$\begin{array}{ll}142 & 483 \text { U.S. } 44 \text { (1987). } \\ 143 & \text { 523 U.S. } 303 \text { (1998). } \\ 144 & \text { 523 U.S. at } 307 \text { n.3. } \\ 145 & \text { Rock, } 483 \text { U.S. at } 61 . \\ 146 & I d .\end{array}$


is reliable." ${ }^{147}$ Indeed, the Court stated, "[t]o this day, the scientific community remains extremely polarized about the reliability of polygraph techniques." ${ }^{\prime 18}$ Therefore, the Court apparently concluded that hypnotically refreshed recall was sufficiently reliable in enough cases to preclude a per se rule, but polygraph evidence was not. ${ }^{149}$ In both cases, the Court evaluated the disputed evidence as a constitutional review-fact, since the sometimes reliability of hypnotically refreshed recall and the less dependable polygraph test were considered as a general matter, given the state of the art of scientific research. In Rock, however, the Court's resolution created an adjudicative-fact inquiry. As the Rock Court made clear, although the per se rule was unconstitutional, hypnotically refreshed recall could still be excluded on a case-by-case basis when the refreshed testimony was unreliable. ${ }^{150}$

The Constitution also affects evidentiary practice when the Court determines whether a particular provision requires a certain kind of proof. For example, in ordinary commitment proceedings, the state must prove, among other things, that the defendant is mentally ill. In Addington v. Texas, ${ }^{151}$ the Court observed that " $[\mathrm{t}]$ here may be factual issues to resolve in a commitment proceeding, but the factual aspects represent only the beginning of the inquiry."152 The Court added, " $[w]$ hether the individual is mentally ill and dangerous to himself or others and is in need of confined therapy turns on the meaning of the facts which must be interpreted by expert psychiatrists and psychologists." ${ }^{153}$ Although the Court has yet to specifically say, it

147 Scheffer, 523 U.S. at 309.

148

Id. at 309-10.

149 Another important difference between Rock and Scheffer was that the former involved the defendant' own testimony while the latter involved an expert witness testifying for the defendant. As a constitutional matter, per se exclusion of the defendant's own testimony may be a more serious matter than excluding one of the defendant's witnesses.

$\begin{array}{ll}150 & 483 \text { U.S. } 44 \text { (1987). } \\ 151 & 441 \text { U.S. } 418 \text { (1979). } \\ 152 & I d . \text { at } 429 . \\ 153 & I d .\end{array}$


would appear that the testimony of a mental health expert would be constitutionally necessary in order to involuntarily commit someone under Addington. In capital sentencing, however, the Court has expressly accepted lay persons' ability to predict dangerousness, ${ }^{154}$ despite substantial evidence that such predictions of violence are prone to error even when done by expert psychiatrists and psychologists ${ }^{155}$

\section{b. Allocating Burdens of Proof}

A central orienting procedural mechanism for adjudicative facts is the standard of proof. Burdens of proof apportion the costs of making mistakes to the parties based on the social and policy consequences associated with one kind of mistake or another. As the Court explained in Addington v. Texas, ${ }^{156}$ the "standard serves to allocate the risk of error between the litigants and to indicate the relative importance attached to the ultimate decision." 157 The Addington Court said that at one end of the spectrum are ordinary civil cases involving monetary disputes between private parties. In these cases, "society has a minimal concern with the outcome, [so] the plaintiffs' burden of proof is a mere preponderance of the evidence."158 At the other end of the spectrum, in criminal cases, "the interests of the defendant are of such magnitude that historically ... they have been protected by standards of proof designed to exclude as nearly as possible the likelihood of an erroneous judgment." 159 According to the Court, "[t]his is accomplished by requiring under the Due Process Clause that the state prove the guilt of an accused beyond a

154 Jurek v. Texas, 428 U.S. 262 (1976).

155 In Barefoot v. Estelle, 463 U.S. 880 (1983), the Court largely accepted the insight that expert predictions of future violence are not reliable. The Court, however, noted absurdly that "[n]either petitioner nor the [American Psychiatric] Association suggests that psychiatrists are always wrong with respect to future dangerousness, only most of the time." Id. at 901.

$\begin{array}{ll}156 \quad & 441 \text { U.S. } 418(1979) . \\ 157 \quad & I d . \text { at } 423 . \\ 158 \quad & I d . \\ 159 & I d .\end{array}$


reasonable doubt."160 Thus, "[i]n the administration of criminal justice, our society imposes almost the entire risk of error upon itself.",161

In Addington, the Court considered what standard of proof applies when a state seeks to involuntarily commit a person to a mental hospital for an indefinite period. The Court initially observed that commitment hearings, which pose "a significant deprivation of liberty," require a standard greater than a preponderance of the evidence. At the same time, the Court found that the criminal standard of proof beyond a reasonable doubt was not appropriate in ordinary civil commitment cases. Instead, it held that an intermediate standard, a clear and convincing evidence requirement, was best tailored to the costs of error in this area. ${ }^{162}$ The Court offered several reasons for this conclusion. First, following an involuntary commitment, the continuing involvement of professionals, family, and friends in the person's treatment would provide opportunities for errors to be corrected. Second, making an error that permits a mentally ill person to live in the general community is not necessarily good for that person: "It cannot be said ... that it is much better for a mentally ill person to 'go free' than for a mentally normal person to be committed."163 And third, the Court observed, "[g]iven the lack of certainty and the fallibility of psychiatric diagnoses, there is a serious question as to whether a state could ever prove beyond a reasonable doubt that an individual is both mentally ill and likely to be violent."164 The Addington Court, therefore, explicitly weighed the costs and benefits associated with the risks of erroneous commitments (i.e., false positives) and erroneous releases (i.e., false negatives), and concluded that proof somewhat greater than preponderance but somewhat less than beyond a reasonable doubt was constitutionally mandated. Whatever one thinks of Addington's bottom

160

161

162
Id. at 424 .

Id. at 423-24.

In the lexicon of this Article, although the issues of mental illness and likelihood of future violence are adjudicative facts, the choice of the clear and convincing evidence standard for civil commitments involves rule-facts.

163

Id. at 430 .

164

Id. 
line, the Court's candidness and the clarity it produces for future cases should be applauded.

\section{JUDICIAL REVIEW OF CONSTITUTIONAL FACT-FINDING}

As demonstrated in the previous sections, facts are endemic to the entire enterprise of constitutional decision making. Constitutional facts are found up, down, and across the judiciary's hierarchical structure. By far the most traditional understanding of constitutional facts involves the bottom-up process whereby trial courts receive evidence regarding disputed facts and this evidence becomes part of the record on appeal. This is only a small part of the overall

picture, however, since facts come into the legal process at many different points, including such common avenues as the briefs of the parties and amici. Moreover, facts do not merely percolate up through the judiciary, but they regularly trickle down from above. In particular, since constitutional facts are intrinsic to both the rules themselves and their application to specific cases, they become part of the doctrine that is set forth by higher courts. This section considers the dynamics of constitutional fact-finding first from the bottom up and then from the top down.

\section{A. Facts Found by Lower Courts}

Constitutional facts are not merely the province of courts, but are regularly found by decision makers across the entire apparatus of government. Police officers make judgments about what constitutes suspicious behavior before making a stop, university administrators assess the empirical benefits of diversity in establishing affirmative action programs, and state legislatures considering legislation mandating the teaching of "intelligent design" might examine the pedagogical benefits that come from teaching it together with the theory of evolution. Virtually every decision having constitutional import is accompanied by findings of fact. Since courts are the ultimate determiners of what the law is, they are obligated to review the factual findings that either implicitly or explicitly support decisions that implicate constitutional values. This raises the important question of how much deference a particular court owes to another 
institution's or another court's constitutional fact-finding. This question arises when courts review the fact-finding of juries, legislatures and administrative agencies. It also arises when appellate courts review lower court fact-finding as well as when lower courts apply higher court precedents premised on those courts' factual findings. In general, a particular court's obligation to defer to another body's fact-finding depends on two things, first, the constitutional relationship between the court and that body, and, second, the constitutional import of the particular finding. In this section, I consider the judiciary's constitutional obligations regarding both finding facts and reviewing facts found elsewhere. ${ }^{165}$

\section{Judicial Review of Constitutional Facts Found at Trial}

At trial, constitutional facts are found by either the trial judge or jury. The jury's obligations under the Constitution are ordinarily limited to adjudicative facts, since rule- and review-facts implicate broad policy matters that fall outside of the jury's charge. ${ }^{166}$ But constitutional adjudicative-facts also implicate policy matters, since their determination affects the exercise of individual rights or the boundaries of constitutional doctrine. An adjudicative fact determination of intentional discrimination or obscenity effectively establishes the content of the respective constitutional provision. This suggests that courts should uniformly apply a stringent standard of review for all constitutional facts found at the trial level, since they all implicate basic constitutional rights or values. And this is uncontroversially the rule with regard to

165 Space prohibits consideration of all the contexts in which courts might review constitutional fact-based decisions by non-judicial government actors. Examples of contexts worthy of such consideration, but beyond the scope of this article, are constitutionally relevant facts found by federal and state agencies, police officers, municipal officials and state legislatures. Section III.B. considers judicial review of Congress' constitutional fact-finding.

166 Although relatively rare, juries are sometimes charged with finding constitutional review-facts. Under the Millertest, for example, juries must decide, among other things, "whether the work, taken as a whole, lacks serious literary, artistic, political, or scientific value." Miller v. California, 413 U.S. 15, 24 (1973). See also City of Monterey v. Del Monte Dunes, 526 U.S. 687, 721 (1999) (Not improper, under $§ 1983$, for a jury to determine "whether a landuse decision substantially advances legitimate public interests within the meaning of [the Court's] regulatory takings doctrine."). 
constitutional-rule and constitutional-review facts. ${ }^{167}$ This section, therefore, focuses on the thornier issue of judicial review of constitutional adjudicative-facts found by juries.

\section{Juries Within the Constitutional Structure}

At least two propositions argue for greater deferential review of adjudicative facts found by juries, and neither is ultimately persuasive in constitutional cases. The first involves the special place held by juries in the constitutional framework. Since juries are creatures of the Constitution itself, they should perhaps receive deference due to their peculiar role in constitutional adjudication. The second proposition is applicable whether the constitutional adjudicative-facts are found by judge or jury and is a shibboleth of evidence law: because appellate courts lack the benefit of seeing witnesses first-hand and thus are unable to judge their credibility, they should defer to trial court factual findings. Thus, for example, under New York

Times $v$. Sullivan, determining whether a false statement was made "with actual malice" is likely to turn on credibility judgments that the trier of fact is uniquely situated to evaluate. In this section, I consider these two issues and conclude that neither provides a convincing basis for adopting a deferential standard of review for constitutional adjudicative-facts found at trial.

\section{a. Juries and constitutional values}

The Sixth and Seventh Amendments guarantee the right to a jury trial in criminal and civil cases, respectively. In most civil and criminal litigation, the jury (or, if no jury, the judge) ordinarily finds adjudicative facts. Procedural rules, including in particular state and federal rules of evidence and procedure, apply to adjudicative fact-finding. Outside of constitutional

167 The most straightforward context for considering judicial power to review constitutional facts is when appellate courts review the legislative fact-finding of lower courts. This doctrine flows naturally from an operating premise that guides all constitutional adjudication. Constitutional rule- and review-facts shape the scope and depth of constitutional provisions and thus superior courts cannot be limited to the findings of fact of inferior courts. When the pertinent factual issue transcends a particular case, higher courts cannot be bound by lower court findings, since the lower courts might have come to different conclusions regarding the same facts. See Lockhart v. McCree, 476 U.S. 162, 168 n.3 (1986) (citing Dunagin v. City of Oxford, 718 F.2d 738, 748 n.8 (5 ${ }^{\text {th }}$ Cir. 1983)(en banc) (plurality opinion of Reavley, J.). 
cases, higher courts typically defer to the fact-finding from below, and this approach is codified in federal practice. ${ }^{168}$ Given their constitutional status and this traditional appellate deference, it might be assumed that juries would receive comparable respect in constitutional cases. But the underlying rationale for the jury system and its historical purposes put it at odds with basic constitutional principles. A jury's primary role is to represent the community from which its members are drawn. In constitutional cases, however, this role comes in conflict with the Constitution's protection of individual rights. As an essentially majoritarian institution, the jury's role clashes with the countermajoritarian values guaranteed by the Constitution.

The jury is generally thought, in theory if not in practice, to be a cross-section of the community whose members bring their experience and commonsense to the application of the law. ${ }^{169}$ Jurors are the neighbors and peers of the accused in criminal cases and the disputants in civil cases. They bring the larger community's perspective into the courtroom. ${ }^{170}$ Jurors represent mainstream society. This grounding in the knowledge of the community permits jurors to bring a practical realism to particular cases and to soften the law's application if it proves too rigid. The jury represents the public and while it may carry out this representation imperfectly, its verdicts are usually accepted as legitimate largely on this basis.

Because of this identification with the public at-large, juries - and jurors - mostly are not held accountable by the public for their decisions. Jurors melt back into the community when

Fed. R. CIV. Proc. 52(a).

169 See Thiel v. Southern Pacific Co., 328 U.S. 217, 220 (1946) (“The American tradition of trial by jury, considered in connection with either criminal or civil proceedings, necessarily contemplates an impartial jury drawn from a cross-section of the community."). See also Oliver Wendell Holmes, Law in Science and Science in Law, 12 HARV. L. REV. 443, 459-60 (1899) (In negligence actions, Holmes observed, jurors "will introduce into their verdict a certain amount ... of popular prejudice, and thus keep the administration of the law in accord with the wishes and feelings of the community.").

170 See Gregg v. Georgia, 428 U.S. 153, 181 (1976) (quoting Witherspoon v. Illinois, 391 U.S. 510, 519, n.15 (1968) (Juries " "maintain a link between contemporary values and the penal system."'). 
they have finished their service. If a verdict is condemned for some reason, it is the institution that ordinarily bears responsibility. Public reaction to perceived juror abuses are almost never directed at particular jurors, but rather at the system as a whole. ${ }^{171}$ Brief reflection, of course, reveals the importance of the individual characteristics of those who compose juries. Indeed, an entire industry - based upon state of the art social science - has grown around the belief that jurors' predilections affect jury verdicts. ${ }^{172}$ Yet, nonetheless, the jury as an institution remains venerated and is widely thought to produce fair and reasonable outcomes.

But many of the reasons that underlie the use of juries in ordinary proceedings are in tension with their use in constitutional cases. In virtually all instances in which juries are used to decide constitutional adjudicative facts, the fundamental liberties and protections of the Bill of Rights and Fourteenth Amendment are involved. These provisions largely enforce countermajoritarian values. The jury, in contrast, is primarily a majoritarian institution. The virtues associated with the representativeness of jurors has little to recommend it in the task of enforcing basic individual liberties. The Bill of Rights is a bulwark against potential majoritarian tyranny. Because the jury represents values associated with the political majority, it cannot be fully entrusted with protection of the values inherent in the Bill of Rights.

Yet, at the same time, juries in popular literature and numerous historical examples operate as defenders of liberty against government tyranny. ${ }^{173}$ Juries sometimes act in counter-

$171 \quad$ Niki Kuckes, The Useful, Dangerous Fiction of Grand Jury Independence, 41 AM. CRIM. L. REV. 1, 2 (2004) (writing that "the disconnect between the rhetoric and reality of the grand jury is not a coincidence, or a historical vestige, but a central and important feature of the modern federal criminal justice system").

172 See generally Shari Seidman Diamond, Truth, the Jury, and the Adversarial System: Truth, Justice, and the Jury, 26 HARV. J.L. \& PUB. POL'Y 143 (2003); Symposium, The Selection and Function of the Modern Jury: Jurors' Attitudes About Civil Litigation and the Size of Damage Awards, 40 AM. U.L. REV. 805 (1991).

173 See generally Kaimipono David Wenger \& David A. Hoffman, Nullificatory Juries, 2003 WIS. L. REV. 1115; David A. Pepper, Nullifying History: Modern Day Misuse of the Right to Decide the Law, 50 CASE W. RES. L. REV. 599 (2000). 
majoritarian ways and, presumably, in defense of individual liberty. When doing so, however, juries do not shed their majoritarian identity. In effect, juries check and balance the majoritarian decision making of the legislative and executive branches of government much as those branches check one another. Juries remain an essentially democratic institution. Indeed, although juries have always had the inherent power of nullification, this power is neither officially sanctioned nor generally acclaimed when it is used. Jurors take an oath to apply the law faithfully and are considered to have failed that obligation if they act contrary to its dictates. While it is true that a juror's responsibility to uphold the law naturally includes fidelity to the Constitution, this does not affect the analysis in any substantial way. Legislators also take an oath to uphold the Constitution. Yet the courts have the responsibility to review legislative actions to ensure that they conform to the Constitution.

Arguably, jury issues that arise under the Sixth Amendment are fundamentally different from those typically arising under the Seventh Amendment. Under the Sixth Amendment, juries are charged with finding facts in the process of applying popularly enacted laws. In these cases, such as New York Times' actual malice standard or Miller's test for community standards of decency, the jury sets constitutional limits as a result of its fact-finding. Under the Seventh Amendment, in contrast, the government is likely to be the defendant and the question presented is whether its actions are constitutional. Takings cases and claims of intentional discrimination under the Equal Protection Clause provide ready examples. Under the Sixth Amendment, the constitutional issue, at least from the jury's perspective, mainly will be implicit, whereas the constitutional query will be front and center in Seventh Amendment cases. Moreover, juries in Sixth Amendment cases are clearly agents of the government in applying the laws of the land, whereas they are charged with judging the government's actions when operating under the Seventh Amendment.

Although these differences are not unimportant, and in individual cases might influence a court's readiness to agree with a jury's fact-finding, they do not affect the fundamental analysis here. Whether arising in criminal cases under the Sixth Amendment or civil cases under the 
Seventh Amendment, the jury embodies majoritarian values in a process designed to guarantee individual rights.

Juries, therefore, like the other representative institutions of government, must be subject to plenary review by the courts when basic liberties are implicated. Indeed, in many constitutional contexts, this independent review has the virtue of operating structurally in a rights-protective fashion. For example, in a criminal obscenity case, two verdicts are possible. If the jury acquits, either because it did not find the material obscene or believed that the obscenity laws were too invasive of free speech, there is no review. A jury decision that is rights protective - or even overly protective - must stand. On the other hand, if a jury convicts on the obscenity charge, its decision is subject to independent review by the courts. ${ }^{174}$ Because courts are the final arbiters of the meaning of the Constitution and thus the ultimate guarantors of the countermajoritarian values inherent in the Bill of Rights, they must review convictions to ensure that they conform with constitutional guarantees.

In civil cases, as well, judges must independently review jury determinations of constitutional facts. The reasons for this exacting review parallel those in the criminal context. Just as in criminal cases, burdensome civil verdicts can chill the exercise of fundamental rights. Indeed, civil litigation, with its lesser burdens of proof and wide exposure to potentially large numbers of litigants, leaves the calculation whether to engage in marginal constitutional activities difficult to make. The uncertainties and vagaries of civil litigation can lead to the chilling of activities well within constitutionally protected zones. Unlike in criminal cases, courts have the power to review verdicts that are either protective or unprotective of basic liberties. It is possible to imagine a standard in civil cases that parallels the one in criminal cases. In effect, this would constitute a one-way ratchet, resulting in deferential review of rights-protective decisions and $d e$ novo review when basic liberties are endangered. But this ignores the other side of the constitutional equation. A court's basic task when interpreting constitutional guarantees is defining the boundary between the legitimate power of the majority to govern as it deems fit and

$174 \quad$ Bose, 466 U.S. 485 (1984). 
the inalienable rights of individuals to sometimes be let alone. Jury verdicts that over-protect liberties tread upon the inherent right of the majority to govern as it pleases. In criminal cases, the constitutional balance is set in a way that prefers that any errors redound to the benefit of the accused, even at some cost to the majority's sovereignty. In civil cases, however, the calculus is different. Judges must ensure that civil juries do not find facts in a way that under-protects individual rights or in a way that under-protects majoritarian will and legitimate government interests. $^{175}$

\section{b. Judging credibility of witnesses}

One of the inveterate principles of modern evidence law is that appellate courts owe deference to the fact-finding of lower courts because triers of fact have the opportunity to observe witnesses and thereby evaluate the credibility of their testimony. ${ }^{176}$ Although little research data are available to demonstrate the validity of this venerable practice, ${ }^{177}$ it is a firmly believed truth of trial and appellate procedure. But even if it is not entirely true, or at least not as true as most courts and scholars believe, this assumption nevertheless has cash value. Its value, however, is largely limited to ordinary litigation. In constitutional cases, a rule of deference is not worth the costs it imposes on basic liberties.

In ordinary litigation, a combination of factors argue in favor of an appellate standard of deference to lower court fact-finding. As an initial matter, a large proportion of adjudicative facts do not recur in other cases and so most adjudicative-fact fact-finding has limited, if any,

175 See Connick v. Myers, 461 U.S. 138, 148 (1983) (reversing a finding in favor of a First Amendment claimant, noting that the question whether the speech was protected or not was a question of law.).

176 See James P. Timony, Demeanor Credibility, 49 CATHOLIC UnIV. L. Rev. 903 (2000).

177 Social science research casts some doubt over the value of demeanor evidence in detecting deception. See Aldert VRIJ, Detecting LiES AND Deceit (2000); see generally Roger C. Park, Empirical Evaluation of the Hearsay Rule, in Peter Mirfield \& Roger Smith, Ed., ESSAYS FOR COLIN TAPPER, 91-106 (LexisNexis UK 2003)). 
precedential force. Questions such as whether the light was red or green or the defendant's car was observed at the scene of the crime, generally do not implicate values or concerns outside of the immediate trial in which they are adjudicated. There are exceptions to this observation, but those exceptions tend to lead courts and scholars away from a rule of deference for the very reasons that they have broader implications. For example, in some contexts, such as when facts often recur, the question arises whether certain behavior is "reasonable" or "unreasonable" - such as stopping to look and listen at a railroad crossing - as a general matter. It has long been accepted that appellate courts play a role in creating standards for situations that repeat. ${ }^{178}$ Similarly, although the question whether it was the victim's blood found on the defendant's coat may be particular to a single case, the issue of the validity of the DNA technology that provided the answer to that question is more general and may have precedential import. In both the tort and scientific evidence examples, there may be good reasons for adopting a less deferential stance when the facts to be found have import beyond an individual case. ${ }^{179}$ This same principle operates in the context of constitutional-adjudicative facts.

A second, and practical, reason for a deferential appellate review standard is that anything more rigorous would produce substantial work for appellate courts, work which would be mainly duplicative of what was done below. Although every case is important, and appellate review of adjudicative fact-finding might catch some errors, on the whole, this argument asserts, the costs

$178 \quad$ United States v. Boyle, 469 U.S. 241, 249 n.8 (1985) ("When faced with a recurring situation ... the Courts of Appeal should not be reluctant to formulate a clear rule of law to deal with that situation."); see Oliver Wendell Holmes, THE COMMON LAw 98 (M. Howe ed. 1963) ("But supposing a state of facts often repeated in practice, is it to be imagined that the court is to go on leaving the standard to the jury forever?"); Monaghan, supra note XX, at 268 (agreeing with Holmes).

179 To date, the United States Supreme Court has treated scientific evidence like all adjudicative-fact evidence and has held that appellate courts owe deference regarding scientific evidence. General Electric Co. v. Joiner, 522 U.S. 136, 145 (1997). Many state supreme courts, in contrast, hold that appellate review should be de novo for scientific propositions that transcend particular cases. See, e.g., State v. Hungerford, 697 A.2d 916, 920 (1997) (“[W]e review the reliability or general acceptance of novel scientific evidence independently when the determination is not likely to vary according to the circumstances of a particular case."). 
to the system would be too great and, indeed, if done conscientiously, would quickly overwhelm appellate courts.

At least in free speech cases, the Court has not been persuaded that independent appellate review of constitutional adjudicative-facts was more work than it could handle. ${ }^{180}$ In fact, the Court describes independent review as a constitutional duty that it is obligated to perform. The primary basis for the Court's assumption of the burdensome task of independent review is the fact that adjudicative-fact resolution in constitutional cases affect the exercise of basic rights and help establish the parameters of the Constitution's boundaries. In Bose, the Court explained the need for independent review in free speech cases in the following way:

[T] he Court has regularly conducted an independent review of the record both to be sure that the speech in question actually falls within the unprotected category and to confine the perimeters of any unprotected category within acceptably narrow limits in an effort to ensure that protected expression will not be inhibited. Providing triers of fact with a general description of the type of communication whose content is unworthy of protection has not, in and of itself, served sufficiently to narrow the category, nor served to eliminate the danger that decisions by triers of fact may inhibit the expression of protected ideas. ${ }^{181}$

Bose clearly recognizes the interconnectedness of constitutional law definition and constitutional law application. The duty to define the Constitution's meaning effectively incorporates the duty to ensure its proper application. This can only be accomplished by some heightened level of review of constitutional adjudicative fact-finding. In free speech cases this is unambiguously accomplished by the use of independent review by appellate courts.

In cases outside free speech, what practice applies to constitutional adjudicative-facts is less clear. Space does not permit a provision-by-provision examination of this question here. As

$180 \quad$ See Cox v. Louisiana, 379 U.S. 536, 541-43 (1965) (reversing state court conviction for breach of the peace, after independent review of state supreme court's characterization of the evidentiary record and rejection of the trial court's "feel" for the evidence); see also NAACP v. Clairborne Hardward Co., 458 U.S. 886 (1982) (rejecting state supreme court's finding that boycott was illegal); Jenkins v. Georgia, 418 U.S. 153 (1974) (rejecting state court jury finding that Carnal Knowledge was "patently offensive.").

$$
\text { Bose, } 466 \text { U.S. at } 505 \text { (footnote omitted). }
$$


a general proposition, however, and for the purposes of the unified theory I propose, it is worth observing that the basic premises supporting independent appellate review in free speech cases

apply equally to adjudicative facts found pursuant to other provisions of the Constitution. ${ }^{182}$ Specifically, the dual concerns stated in Bose - the need to ensure that particular cases are adjudicated correctly as falling within or outside constitutionally defined categories and judicial regard for the impact litigation has on similarly situated cases - are not unique to free speech challenges. As is true with other constitutional facts, the degree of rigor courts bring to appellate review should depend on the constitutional values at stake in the respective context. This must be decided as a matter of law.

The more fundamental the right or the more protected the class of individuals affected by the government or state action, the greater the need for independent review. Hence, cases raising questions of intentional discrimination against suspect classes or which threaten deprivations of liberty, present compelling arguments for strong independent review. At the same time, when constitutional adjudicative-facts are presented, but the right or value is not fundamental, independent review should be more cursory, but still not perfunctory. For example, in Cruzan v. Director, Missouri Department of Health ${ }^{183}$ the Court recognized that a competent adult has a liberty interest in refusing unwanted medical treatment. But the right itself was not described as fundamental. As a consequence, future adjudication regarding individual claimants to this right should not expect strong independent review of the factual question whether the right had been expressed or not. ${ }^{184}$

\section{B. Judicial Review of a Legislature's Fact-Finding}

182 But see Rogers v. Lodge, 458 U.S. 613 (1982) (without specific explanation, the Court applied the clearly erroneous standard to the lower court's finding that the defendant had purposely discriminated in violation of the Fourteenth Amendment's Equal Protection Clause).

183 497 U.S. 261 (1990).

184 In Cruzan, the Court upheld a Missouri law that required claimants to the right to demonstrate by clear and convincing evidence that they wished to refuse medical treatment. This is a constitutional adjudicative-fact. 
As might be expected, a legislature's findings of fact tend to involve primarily constitutional legislative-facts. Moreover, legislatures ordinarily limit their fact-finding to constitutional review-facts, ${ }^{185}$ which typically operate to justify a particular action that may be challenged under the Constitution. Such facts might support either the ultimate objective of the law or be used to defend the means chosen to accomplish a particular objective. Complicating matters somewhat, legislatures sometimes make their factual findings explicit, and sometimes the legislature's factual bases are attributed to it after the fact by the lawyers or, occasionally, by the courts.

Despite the seeming complexity of this arena, the constitutional resolution of the question of what level of deference is owed legislative fact-finding is fairly straightforward. The standard of review of legislative fact-finding should abide by the same basic principle that guides the entire enterprise of judicial review when laws implicate constitutional values. In a wide variety of constitutional contexts, the Supreme Court has established various substantive tests that differ in their rigor depending on the depth of the constitutional value involved. For instance, in Due Process and First Amendment cases, the Court ordinarily applies strict scrutiny when a fundamental right is implicated, but only rational basis review when the right is not fundamental. ${ }^{186}$ The Court has framed its analysis in Equal Protection Clause cases similarly, applying strict or intermediate scrutiny when a state action discriminates on the basis of a suspect

185

There are exceptions, and legislatures have sometimes sought to set-forth both constitutional rule-facts and constitutional adjudicative-facts. In Webster v. Reproductive Services, for example, the Court reviewed a Missouri law which provided in the preamble that "life begins at conception," thus seemingly contradicting the constitutional-rule fact adopted in Roe v. Wade, constructing the trimester framework around viability. Although the Roe Court expressly declined to say when "life" began, it also precluded state legislatures from enacting laws that would be premised on an alternative view of the facts. The Webster Court let the preamble stand, finding that it had no operative effect. Legislative attempts to establish constitutional adjudicative-facts are relatively rare and when they occur are likely to run afoul of the principles of separation-of-powers. See, e.g., Bush v. Schiavo, 885 So.2d 321 (Fla. 2004) (finding "Terri's Law" unconstitutional in authorizing governor to grant one-time stay to prevent the withholding of nutrition and hydration from a patient).

186 See generally, Ashutosh Bhagwat, Purpose Scrutiny in Constitutional Analysis, 85 CAL. L. REV. 297 (1997). 
classification, but only rational basis review when no such classification is involved. This "tailoring" analysis is principally empirical, and courts' deference to legislative fact-finding diminishes in direct proportion to the fundamentality of the right. ${ }^{187}$ The more important the constitutional value, the more rigorous the review. When fundamental rights are implicated, courts apply strict scrutiny and the government must demonstrate that the law is closely related to a compelling government interest. When a constitutional right is deemed non-fundamental, in contrast, courts determine merely whether the law is rationally related to a legitimate government interest. Judicial time and attention, therefore, are tied to the depth of the alleged constitutional infringement. This basic insight should guide courts' hands in reviewing a legislature's factfinding generally. Hence, the greater the constitutional demand for oversight of legislative decision-making - i.e., the more deeply constitutional values are implicated - the less deferential courts should be to a legislature's factual findings.

Unfortunately, the answer to the question of how much deference is owed cannot be premised simply on preexisting standards of judicial review, such as rational basis or strict scrutiny. Although basic doctrine often distinguishes in theory between strict scrutiny and rational basis review, the actual practice by which courts safeguard basic liberties is rather more complicated and considerably more convoluted. In the context of individual freedoms, two problems, in particular, are worthy of note. First, over the last thirty years, the Court has regularly departed from a strict and categorical approach to two-tiered scrutiny. ${ }^{188}$ The clearest example of this is the Court's adoption of intermediate scrutiny in several constitutional areas, including gender discrimination ${ }^{189}$ and regulation of commercial speech. ${ }^{190}$

187 See generally Gerald Gunther, The Supreme Court, 1971 Term-Foreward: In Search of Evolving Doctrine on a Changing Court: A Model for a Newer Equal Protection, 86 HARV. L. REV. 1, 33-36 (1972).

188 See generally Calvin Massey, The New Formalism: Requiem for Tiered Scrutiny?, 6 U. PA. J. Const. L. 945 (2004). See, e.g., Craig v. Boren, 429 U.S. 190 (1976).

190 See, e.g., Cent. Hudson Gas \& Elec. Corp. v. Pub. Serv. Comm. of N.Y., 447 U.S. 557 (1980). 
The second problem is that in different constitutional contexts the same test is manifested in different ways. In Central Hudson Gas \& Electric Corp. v. Public Service Comm. of N.Y., for example, the Court applied intermediate scrutiny to commercial speech and elaborated a fourpart test to determine whether a regulation infringed upon the First Amendment Right. In United States $v$. Virginia (the VMI case), ${ }^{191}$ the Court similarly applied intermediate scrutiny but noted that the government must have an "exceedingly persuasive" justification for discriminating on the basis of gender, and, in that case, applied it rigorously to strike down a scheme of separate education that had been upheld by both the trial and appellate courts below. In United States $v$. O'Brien, ${ }^{192}$ the Court framed still another intermediate scrutiny test, this time for expressive conduct, but applied it with much less rigor then might be expected from a test of heightened scrutiny. ${ }^{193}$ Intermediate scrutiny, as a practical matter, has become something of a catch-all for a constitutional domain ranging from rational basis analysis with bite to strict scrutiny without teeth.

In many other constitutional areas, the Court's statement of review is less than plainly stated, or, at least, not plainly applied. In Grutter v. Bollinger, for instance, the Court applied a sort of deferential strict scrutiny to the University of Michigan's affirmative action program on the theory that universities enjoy a special privilege to make education judgments by virtue of the First Amendment. ${ }^{194}$ Outside of the Bill of Rights, the Court similarly has failed to state with precision the standard of review that applied. For instance, the Court has employed the

191 518 U.S. 515 (1996).

192 391 U.S. 367 (1968).

193 See generally Eugene Volokh, Speech as Conduct: Generally Applicable Laws, Illegal Courses of Conduct, "Situation-Altering Utterances," and the Uncharted Zones, 90 CORNELL L. REV. 1277, 1282-83 (2005).

194

Grutter v. Bollinger, 539 U.S. 306, 329 (2003) ("We have long recognized that, given the important purpose of public education..., universities occupy a special niche in our constitutional tradition."). 
deferential test in dormant commerce clause cases in a non-deferential manner, ${ }^{195}$ and under the generally deferential Commerce Clause, the Court has applied the test non-deferentially. ${ }^{196}$ In general, the underlying principle the Court seems to apply in its cases is to be less deferential to legislatures the more deeply constitutional values are implicated by the legislation. ${ }^{197}$ But the justices are not always candid or consistent regarding their views of the depth of particular constitutional provisions. ${ }^{198}$

195 See, e.g., Kassel v. Consolidated Freightways Corp., 450 U.S. 662, 675-76 (1981) ("Less deference to the legislative judgment is due, however, where the local regulation bears disproportionately on out-of-state residents and businesses."; S. Pac. Co. v. Ariz., 325 U.S. 761, 770-80 (1945) (removing extremely detailed railroad safety findings made by trial court without any mention of deference to legislature).

196 See United States v. Morrison, 529 U.S. 598, 615 (2000) (criticizing Congress's "method of reasoning"); United States v. Lopez, 514 U.S. 549, 562 (1995) ("as part of our independent evaluation of constitutionality under the Commerce Clause we of course consider legislative findings, and indeed even congressional committee findings, regarding effect on interstate commerce") (emphasis added), citing Heart of Atlanta, Inc. v. United States, 379 U.S. 241 (1964). See, also, Lucas v. S.C. Coastal Council, 505 U.S. 1003, 1026 (1992) (“[T]he legislature's recitation of a noxious-use justification cannot be the basis for departing from our categorical rule that total regulatory takings must be compensated."); Nollan v. Cal. Coastal Comm., 483 U.S. 825, 838 (1987) (rejecting Commission's finding that beach access easement was factually related to construction of a beach house).

197 Compare United States v. Carolene Products Co., 304 U.S. 144, 152 ("regulatory legislation affecting ordinary commercial transactions is not to be pronounced unconstitutional unless in the light of the facts made known or generally assumed it is of such character as to preclude the assumption that it rests upon some rational basis within the knowledge and experience of the legislators") with id. at 153, n.4 ("There may be narrower scope for operation of the presumption of constitutionality when legislation appears on its fact to be within a specific prohibition of the Constitution, such as those of the first ten amendments, which are deemed equally specific when held to be embraced within the Fourteenth.").

198 Compare Gonzales v. Raich, 125 S. Ct. 2195, 2215 (June 6, 2005) (holding that the Controlled Substances Act that criminalized the manufacture, distribution or possession of marijuana to intrastate growers and users of marijuana for medical purposes did not violate the Commerce Clause) with United States v. Morrison, 529 U.S. 598, 602 (2000) (holding that Congress exceeded its authority under the Commerce Clause by enacting a civil rights remedy provision in the Violence Against Women Act); see also Gonzales v. Raich, $125 \mathrm{~S}$. Ct. at 222728 (O'Connor, J., dissenting) (arguing that "[i]f, as the Court claims, today's decision does not break with precedent, how can it be that voluminous findings, documenting extensive hearings about the specific topic of violence against women, did not pass constitutional muster in 
Although the exact tests used by the Court remain murky, the Court has never shied away from the task of reviewing a legislature's constitutional fack finding when basic constitutional values are implicated. Examples abound in the Court's enforcement of the First Amendment guarantee of free speech. ${ }^{199}$ Similarly, in the Equal Protection context, the Court has been quite willing to question or ignore legislative findings when suspect classifications are involved. ${ }^{200}$ Even under the arguably more permissive intermediate scrutiny applied to gender-based classifications, the Court has displayed little deference to legislative fact-finding. ${ }^{201}$ Finally, the Court's privacy cases under the Due Process Clause of the Fourteenth Amendment display the

Morrison, while the CSA's abstract, unsubstantiated, generalized findings about controlled substances do?").

199 See, e.g., Ashcroft v. Free Speech Coalition, 535 U.S. 234, 241-42, 251-58 (200) (setting forth Congress's enacted findings and later rejecting each as insufficient to support constitutionality); Bartnicki v. Vapper, 532 U.S. 514, 531n.17 (2001) (noting that "the dissent argues that we have not given proper respect to 'congressional findings' or to 'Congress's factual predictions'... [b]ut the relevant factual foundation is not to be found in the legislative record") (citation omitted); Whitney v. Cal., 274 U.S. 357, 374 (1924) (Brandeis, J., concurring) (rejecting the assertion in Gitlow v. N.Y., 268 U.S. 652, 668-671, that a legislative determination that "utterances advocating the overthrow of organized government by force, violence and unlawful means, are so inimical to the general welfare and involve such danger of substantive evil that they may be "given great weight").

200 See, e.g., Adarand Constructors v. Pena, 515 U.S. 200, 226-27 (1995) (reaffirming the Croson view that "all racial classifications, imposed by whatever federal, state, or local government actor, must be analyzed by a reviewing court under strict scrutiny"); Richmond v. J.A. Croson Co., 488 U.S. 469, 500 (1989) ("none of [the City Council's] 'findings,' singly or together, provide the city of Richmond with a 'strong basis in evidence for its conclusion that [race-based] remedial action was necessary.'”).

201 See, e.g., Craig v. Boren, 429 U.S. 190, 200-01 (1976) (dismissing statistics offered to support State legislation imposing a different minimum age, based on gender, for purchasing beer as weak, inaccurate, and failing to closely serve the objectives of the legislation); United States v. Va., 518 U.S. 515, 543 (1996) (dismissing the testimony of Virginia's experts that the admission of women to the all-male Virginia Military Institute would be so radical as to destroy the program as an unproven judgment, "a prediction hardly different from other 'selffulfilling prophec[ies]' once routinely used to deny rights or opportunities.") (internal citations omitted). But see Nguyen v. I.N.S., 533 U.S. 53, 73 (2001) (upholding different citizenship rules according to the gender of the citizen-parent). 
same disregard for the findings of legislatures, ${ }^{202}$ and this is true even when the Court explicitly employs the most deferential standard of rational basis review. ${ }^{203}$

Seemingly inconsistent with this steady drumbeat of little or no deference across a large part of the constitutional spectrum, the Court regularly extols the fact-finding capabilities of legislatures. ${ }^{204}$ This compliment to legislatures' empirical acumen is a function primarily of the Court's recognition that legislators typically have greater resources at their disposal than judges. ${ }^{205}$ Legislators can sponsor research, hold hearings, and call expert witnesses. They also have great flexibility to refine their research questions and redefine the scope, direction, and size of any inquiry. Justice Souter made this point in his concurrence in Washington $v$. Glucksberg, ${ }^{206}$ writing that legislatures "have more flexible mechanisms for fact-finding than the judiciary," as well as "the power to experiment, moving forward and pulling back as facts emerge

$202 \quad$ See, e.g., Griswold v. Conn., 381 U.S. 479, 505 (1965) (White, J., concurring) (rejecting asserted purpose that ban on contraceptive use furthered "the State's policy against all forms of promiscuous or illicit sexual relationships, be they premarital or extramarital"); Poe v. Ullman, 367 U.S. 497, 545 (1961) (Harlan, J., dissenting) (scrutinizing whether State's asserted goals are furthered by criminalizing contraceptive use); Skinner v. Okla., 316 U.S. 535, 546 (1942) (Jackson, J., concurring) (rejecting state's theory of biological determinism); Pierce v. Soc'y of Sisters, 268 U.S. 510, 534 (1925) (finding right to send one's children to private school and noting "there is nothing in the present records to indicate that [private schools] have failed to discharge their obligations to patrons, students or the State ... [a]nd there are no peculiar circumstances or present emergencies which demand extraordinary measures relative to primary education"); Meyer v. Neb., 262 U.S. 390, 402 (1923) (legislative preference for forming a more homogeneous society insufficient to justify ban on teaching of foreign languages).

203 See, e.g., Lawrence v. Texas, 539 U.S. 558, 577-78 (2003).

204 See McCleskey v. Kemp, 481 U.S. 279, 319 (1987) (quoting Gregg v. Georgia, 428 U.S. 153, 186 (1976) (Legislatures "are better qualified to weigh and "evaluate the results of statistical studies in terms of their own local conditions and with a flexibility of approach that is not available to the courts.'”).

205 In the case of Congress's empirical acumen, the Court's respect for a coordinate branch of government might also play a role in statements of deference.

206

521 U.S. 707 (1997). 
within their own jurisdictions." 207 Courts, by comparison, are more limited, since they cannot initiate or fund research, and the factual questions that come before them are fairly well defined by either the controlling law or the parties. Judges, unlike legislators, rarely ask witnesses questions and usually do not specify which experts will be called to testify. These institutional differences have led the Court to repeatedly express its preference for Congressional fact-finding and point out its own limited capacity to match the resources legislatures can bring to fact-based inquiries. $^{208}$

While the power of legislatures to gather facts must be duly recognized, this acknowledgment does not necessarily affect the standard of review courts bring to legislative fact-finding. Courts too are fact-finders. Legislatures may excel in defining and financing research, but the courts excel at hearing controverted evidence and coming to a decision free of partisan influence. Particularly federal courts, largely insulated from the shifting political tides, are able to evaluate evidence in a systematic and careful fashion. District courts hear the evidence and accordingly must evaluate the credibility of witnesses and the reliability and validity of proffered expert testimony. Moreover, there is rarely a shortage of qualified expert opinion. Especially in high-profile constitutional litigation, the factual questions turn largely on disputed research data and expert evidence regarding general research findings and professional opinion. While the judiciary may not be as well designed institutionally as the legislative branch to gather these data, courts are especially well designed to evaluate them.

Adopting a non-deferential standard of review in constitutional cases will not dissuade legislatures from compiling a full record. Indeed, a legislature that anticipates confronting a

207 Id. at 788 .

208 Bartnicki v. Vopper, 532 U.S. 514 , 550 (2001) (Rehnquist, C.J. dissenting) ("Congress is far better equipped than the judiciary to evaluate the vast amounts of data bearing upon complex issues"); Walters v. Nat'l Ass'n of Radiation Survivors, 473 U.S. 305, 330 (1985) ("When Congress makes findings on essentially factual issues such as these, those findings are of course entitled to a great deal of deference, inasmuch as Congress is an institution better equipped to amass and evaluate the vast amounts of data bearing on such an issue"). 
rigorous standard of review when the matter reaches the courts should be expected to do more to ensure a compelling factual record. A legislature's natural advantage to invest in research and gather factual knowledge should allow it to put together a full record for the courts' inspection. In constitutional contexts in which the courts are obligated to protect basic liberties or enforce structural barriers, they must independently review the bases for legislative actions. Rigorous and close evaluation of a legislature's factual premises in appropriate cases maximizes the benefits to be gained from each of the two branches of government. Legislatures' greater capacity to produce factual information complements the judiciary's natural advantage of reviewing the facts largely insulated from the pressures of partisan politics. The better the record amassed by a legislature, the easier will be the judiciary's task in carrying out its constitutional function.

\section{Lower Court Review of Higher Court Fact-Finding}

The standard model of constitutional fact-finding is limited to the description of factual findings as they move up the judicial hierarchy. The previous sections focused primarily on establishing a coherent foundation for this standard model of facts being integrated into constitutional doctrine as cases ascend toward the Supreme Court. But inherent in my approach was the basic insight that facts are dynamic over time, in that they themselves might change with advancing technology or an evolving society, or that our knowledge of them might change as more research is completed. This insight poses a crisis for the standard model, since the model entirely fails to account for it. Specifically, what happens in constitutional jurisprudence when the facts change? In this section, I consider the most controversial aspect of my uniform theory. In particular, can lower courts revisit precedent in order to adjust earlier rulings to account for a changed factual landscape? My answer to this question is sometimes yes, sometimes no, and is contingent on the type of fact involved.

\section{General Considerations}

It goes without saying that the judiciary is structured hierarchically. Higher court legal judgments are binding on lower courts. This would appear to be especially so in the 
constitutional arena. But what happens when settled law relies upon changeable facts? If the predicate facts of a higher court's holding change, should subsequent courts revisit the holding given this new information? The answer to this might very well depend on an assortment of considerations. Indeed, this subject implicates many foundational premises of the American constitutional system. Given the richness of the subject and the large role facts play in constitutional decision making, it is surprising that the Court has given so little attention to this matter.

Perhaps the only time that the issue was squarely presented regarding a lower court's power to distinguish precedent on the basis that predicate facts had changed was in Roper $v$. Simmons. ${ }^{209}$ The principal issue in Roper concerned the constitutionality of imposing the death penalty on those who were sixteen or seventeen years-old when they committed their crimes. In 1989, in Stanford v. Kentucky, ${ }^{210}$ the Court had held that this practice did not offend the Constitution. In 2003, however, the Missouri Supreme Court distinguished Stanford on the basis that the predicate facts on which that decision rested had changed and ruled that executing those who had committed their crimes when they were under 18-years of age violated the Eighth Amendment's prohibition of cruel and unusual punishment. ${ }^{211}$ In particular, the Missouri Court in Roper found a shift in public sentiment nationally indicating that such punishment now ran afoul of contemporary standards of decency. The Supreme Court granted certiorari on two questions. The first was the constitutionality of executing those who had committed their crimes as juveniles. The second concerned the question at issue here: "Once this Court holds that a particular punishment is not 'cruel and unusual' and thus barred by the Eighth and Fourteenth Amendments, can a lower court reach a contrary decision based on its own analysis of evolving standards?"212

$209 \quad 125$ S.Ct. 1183 (2005).

210492 U.S. 361 (1989).

211 State ex. rel. Simmons v. Roper, 112 S.W.3d 397 (Mo. 2003).

212 Roper v. Simmons, Questions Presented for Review, Supreme Court of the United States (2005), http://www.supremecourtus.gov/qp/03-00633qp.pdf. 
Justice Kennedy's opinion for the Court did not mention, or even allude to, the second question presented. The Court, instead, limited its analysis to the principal question, the constitutionality of executing minors. Affirming the Missouri decision, the Court held that imposing capital punishment on juveniles violated the Eighth Amendment's ban on cruel and unusual punishment. The Court relied on three grounds for its holding, all of which involved statements of scientific or social scientific fact. First, based on surveys of state practice, the Court agreed with the Missouri court that since Stanford the national consensus had shifted sufficiently to cast doubt that executing juveniles met modern "civilized standards of decency." 213 In addition, second, the Court found that juveniles were distinguishable from adults in three ways that indicated that they "cannot with reliability be classified among the worst offenders."214 These grounds included juveniles' (1) underdeveloped sense of responsibility and general immaturity as compared to adults, (2) susceptibility to outside influence and peer pressure, and (3) lack of fully formed characters. These three characteristics indicated juveniles' diminished culpability which, according to the Court, meant "that the penological justifications for the death penalty apply to them with lesser force than to adults." ${ }^{215}$ The final argument advanced by the Court to support its holding was "the stark reality that the United States is the only country in the world that continues to give official sanction to the juvenile death penalty."216

While the majority opinion ignored the question of a lower court's power to find facts contrary to higher court authority, the separate dissents of Justices O'Connor and Scalia did not. Both justices took extreme umbrage at the lower court's temerity. O'Connor wrote that she took

$213 \quad I d$. at 1190.

$214 \quad I d$. at 1195.

$215 I d$. at 1196. The Court rejected the possibility of evaluating each juvenile defendant's maturity on a case by case basis. "The differences between juvenile and adult offenders are too marked and well understood to risk allowing a youthful person to receive the death penalty despite insufficient culpability." Id. at 1197.

Id. at 1187. 
"issue with the Court's failure to reprove, or even to acknowledge, the Supreme Court of Missouri's unabashed refusal to follow our controlling decision in Stanford." ${ }^{217}$ She conceded that the Eighth Amendment rule calling for a contemporary assessment of "evolving standards of decency" meant that "significant changes in societal mores over time may require us to reevaluate a prior decision." 218 But, she emphasized, "it remains 'this Court's prerogative alone to overrule one of its precedents.", ${ }^{219}$ Finally, she warned, “[b]y affirming the lower court's judgment without so much as a slap on the hand, today's decision threatens to invite frequent and disruptive reassessments of our Eighth Amendment precedents.",220

Justice Scalia similarly found the contumacious behavior of the lower court intolerable. As an initial matter, he rejected the entire premise that the Eighth Amendment's meaning changes with evolving standards of decency. ${ }^{221}$ Scalia said that it "add[s] insult to injury" that the "Court affirms the Missouri Supreme Court without even admonishing that court for its flagrant disregard of our precedent in Stanford.",222 The lower court's insolence, according to Scalia, was a product of a jurisprudence that permitted the Constitution's meaning to change as circumstances changed. He observed as follows:

The Court has purported to make of the Eighth Amendment ... a mirror of the passing and changing sentiment of American society regarding penology. The lower courts can look into that mirror as well as we can; and what we saw 15 years ago bears no necessary

$217 \quad I d$. at 1209 (O’Connor, J., dissenting).

$218 \quad I d$.

219 Id. (quoting State Oil Co. v. Khan, 522 U.S. 3, 20 (1997) (emphasis added by O'Connor)).

$220 \quad$ Id. at $1209-1210$.

$221 \quad I d$. at 1217 (Scalia, J., dissenting) ("What a mockery today's opinion makes of Hamilton's expectation [that the judiciary will be the least dangerous branch], announcing the Court's conclusion that the meaning of our Constitution has changed over the past 15 years - not, mind you, that this Court's decision 15 years ago was wrong, but that the Constitution has changed.") (emphasis supplied by author).

$222 I$ Id. at 1229. 
relationship to what they see today. Since they are not looking at the same text, but at a different scene, why should our earlier decision control their judgment? ? $^{223}$

In addition, Scalia noted that this danger was not limited to any "special character" of the Eighth Amendment. "Nothing in the text reflects such a distinctive character - and we have certainly applied the 'maturing values' rationale to give brave new meaning to other provisions of the Constitution, such as the Due Process Clause and the Equal Protection Clause."224 Left unchecked, Scalia warned, the majority's permissiveness would allow lower courts to reinterpret the Constitution "whenever they decide enough time has passed for a new snap shot."225 This outcome "leaves this Court's decisions without any force," a result that "crown[s] arbitrariness with chaos."226

Possibly the starkest example of the nightmare Justice Scalia envisions, and one that might unsettle the more liberal-minded justices as well, comes from Stell v. Savannah-Chatham, discussed in Section I. In summarily reversing the Stell district court, the Fifth Circuit stated that "no inferior federal court may refrain from acting as required by [the Brown] decision even if such a court should conclude that the Supreme Court erred as to its facts or as to the law."227 Further, the circuit court discounted the importance of the social science evidence for the Brown result. "We do not read the major premise of the decision of the Supreme Court in the first Brown case as being limited to the facts of the cases there presented. We read it," the court observed, "as proscribing segregation in the public education process on the stated ground that

$223 \quad$ Id. at $1229-30$.

$224 \quad I d$. at 1228 n.9 (citing Laurence v. Texas, 539 U.S. 558, 571-573 (2003), United States v. Virginia, 518 U.S. 515, 532-534 (1996), Planned Parenthood of Southeastern Pa. v. Casey, 505 U.S. 833, 847-850 (1992)).

$225 \quad I d$. at 1230.

$226 \quad I d$.

227 333 F.2d at 61. 
separate but equal schools for the races were inherently unequal.",228

The Fifth Circuit, therefore, made two arguments for why the Stell trial court had erred. The first was that a lower court was bound by the factual findings and legal conclusions of a higher court, and the second was that the holding in Brown had not depended on the factual findings set forth in the opinion. The latter argument was not controversial in itself, since it simply concerned the appellate court's assertion that the trial court had misinterpreted the Brown decision. Whereas the trial court had believed that Brown was premised on the fact-based psychological consequences of segregation, the Fifth Circuit held that it rested on the legal principle of equality. If this legal assessment had been the full extent of the Fifth Circuit's decision, it would have been unremarkable.

The Fifth Circuit's former statement - that the trial court had inappropriately reconsidered factual findings previously made by a higher court - is considerably more open to question. The Fifth Circuit essentially held that lower courts do not have the power to reconsider the predicate facts of otherwise binding precedent. But the court did not explain the basis for this conclusion. It simply assumed that it was obviously correct, much as Justice O'Connor assumed the obviousness of this determination in Roper. The conclusion that lower courts cannot revisit constitutional facts - and, in due course, higher court constitutional precedent - is not at all obvious. This statement of the law is too broad, for it fails to consider the different kinds of constitutional facts that percolate up and trickle down the hierarchy of the courts. While this principle of deference might be obviously correct regarding some kinds of constitutional facts, it is not as regards all kinds of constitutional facts. The three basic kinds of fact - rule, review, and adjudicative - present very different issues regarding their place in the lexicon of constitutional doctrine.

\section{Specific Considerations}

A basic argument of this Article is that facts should be taken seriously when they are 
offered as a component of constitutional decision making. Implicit in this argument is the assumption that "facts" are out there to be found. I don't mean to suggest, however, that constitutional facts - of whatever variety - can always be found with a high degree of certainty or without a good deal of baggage associated with the socially constructed worlds of their finders. Facts, whether they concern the question of when a fetus has the lung capacity to survive outside the womb or the question of the empirical consequences of locating adult-entertainment establishments in particular neighborhoods, are known with more or less certainty. The potential for error associated with virtually all fact-finding means that, as a normative matter, the law must allocate the risks associated with making a mistake. The law primarily accomplishes this through procedural devices such as burdens of proof and presumptions. In criminal cases, for instance, where the consequences of making an error of guilt ("false positive") are substantial, the "beyond a reasonable doubt" rule is used; in civil cases, in which similar errors of inclusion have less gravity, the more lenient "preponderance of the evidence" standard is employed. In constitutional fact-finding, the prospect of error (whether of the false positive or false negative variety) should be a key element in the development of rules of procedure. As a consequence, therefore, the issue of how well the fact must be known is a legal determination. Viability, for example, is actually a statistical prediction of fetus survivability. Whether the probability of survival must be $10 \%$ or $90 \%$, estimates that directly correspond with gestational age, must be resolved as a matter of law. What the probability of survival is at, say, 27 weeks, on the other hand, is a constitutional review-fact.

Professor Davis' original division between legislative and adjudicative facts was based largely on the identity of the fact-finder deciding the fact, rather than the legal relevance of the fact. If the fact was found by lawmakers, it was legislative, and if found by the trier of fact (jury, or, if none, judge), it was adjudicative. There was thus a degree of circularity in his taxonomy. The very same fact might be described as adjudicative, because it was part of a jury's deliberations, and legislative, because a lawmaker used it to form or interpret the law. To a large extent, I turn Davis' scheme on its head. In my taxonomy, facts are classified on the basis of the demands of constitutional doctrine. What facts are material to the resolution of a constitutional 
dispute, therefore, depend on a reading of the Constitution. Thus, for example, whether the issue of the factual consequences of a spousal notification provision, as presented in Casey, is a review-fact or an adjudicative-fact depends on the values inherent in the Due Process Clause. Similarly, in Roper, the Court interpreted the factual issue of minors' psychological and physiological cognitive development as a class-based review-fact, rather than a subject of caseby-case determination as an adjudicative fact. The decision to treat minors as a class, rather than require individualized assessments of a minor's particular cognitive capacity, was a function of the Court's interpretation of the Eighth Amendment. ${ }^{229}$ As a general matter, very different consequences follow depending on what type of constitutional fact is involved. The costs and benefits associated with those consequences are a matter of constitutional import. The following sections consider some of those costs and benefits in regard to the single issue of whether a lower court should have the authority to reconsider higher court precedent when the facts - or our knowledge of the fact - on which that precedent depend have changed.

\section{a. Constitutional rule-facts}

Constitutional-rule facts are relevant to the definition of, or establish the foundation for, a constitutional rule or standard. Although the line between rule and review facts can sometimes be blurry, in most cases the distinction will be clear. The distinction is based on the difference between interpreting the Constitution and applying it. In Roe v. Wade, for instance, the Court established viability as the point in time when the state's interests were sufficiently compelling to justify prohibitions of abortion, subject to exceptions for the health of the mother. In Casey, the Court reaffirmed this rule, calling it the "central holding" of Roe. The selection of viability was based on a host of arguments, including historical practices, the nature of the doctor-patient relationship, precedent, and, in the end, the Court's assessment of the strength of the state's interest in preserving the potential life of the fetus. The Court balanced the nature of the right against the strength of the state's interest and established a standard that was fastened to the point

229 Roper v. Simmons, 125 S.Ct. 1183, 1196 (2005) (rejecting argument that because some juveniles have equal capacity to that of adults, that culpability assessments in capital cases should be made on an individualized case-by-case basis). 
at which a fetus was likely to survive outside the womb. Viability thus became the rule to be applied in subsequent cases.

Describing viability as the rule to be applied suggests that if medical technology were to change, the contour of the "right" would change as well. Hence, if viability is the rule, and viability moves from 22-24 weeks to 10-12 weeks as a matter of medical fact, then the right of reproductive choice should presumably move as well. Indeed, this is one of the principal features of employing rules that depend on possibly different circumstances occurring from those that existed when the rule was first set-forth. It could be argued that the compromise point - viability - was really chosen for certain unstated reasons, such as giving the pregnant woman sufficient time to exercise her right to an abortion. Under this interpretation of Roe, the "rule" is not viability at all, but rather the end of the second trimester - 24 weeks - approximately the time at which viability occurred in 1973. Of course, changes in technology or medical science would not affect the 24-weeks rule. But the Court never said that the rule was 24-weeks; it said, and thereafter has maintained, that the rule is "viability" - whenever that should occur.

The issue of what the "rule" is in Roe is reminiscent of the debate following Brown $v$. Board of Education as to whether the holding in that case depended on the factual question of segregation's effects or on the inherent inequality of separate schooling. If the former, then subsequent research could result in different outcomes and segregated education might pass constitutional muster. This, of course, was the Stell district court's reading of Brown. If the latter, the rule would be that segregated schools are per se unconstitutional, the Fifth Circuit's reading of the case. Given the modern test of strict scrutiny, it appears that the district court's interpretation of Brown was the more accurate one and that, at least if the state's interests were compelling enough, segregation might be constitutional under certain, albeit extraordinary, circumstances. $^{230}$ If this interpretation is correct, then the Stell court's attempt to distinguish

$230 \quad$ See Johnson v. California, 543 U.S. 499 (2005) (holding that strict scrutiny applies to state policy of segregating prisoners by race, and remanding for determination whether the state has a compelling justification and its means are narrowly tailored to achieve that purpose). 
Brown based on different factual circumstances was wrong because it got the facts wrong, not because it should have refrained from any reconsideration of how the equality rule of Brown should be applied when the factual circumstances have changed. ${ }^{231}$

Similarly, subsequent precedent should reveal whether the rule in Roe was viability or 24weeks. If the former, then changing technology should lead the Court to contemplate an alteration in the 24-week point-in-time, whereas if the latter, then 24-weeks should remain inviolate, subject always to the possibility of it being replaced with another rule. The answer seemed to come from Webster v. Reproductive Health Services. ${ }^{232}$ In Webster, the Court upheld a Missouri law that, among other things, required physicians to use medically appropriate tests to determine whether a fetus was viable at twenty or more weeks of gestational age. ${ }^{233}$ Although the Court did not discuss the issue explicitly, it effectively accepted the Missouri scheme of treating viability as a constitutional adjudicative-fact. After 20 weeks, the viability of every fetus was to be measured individually. In contrast, if Roe had stood for an inviolate rule of 24-weeks, the Missouri viability testing provision would have been invalid as a matter of law. Under Roe, therefore, at least as it is presently applied, viability is the rule and, in some situations, will be applied on a case-by-case basis.

The decision in Roe to adopt a rule employing the medical concept of viability also depended partly on factual arguments. In particular, Justice Blackmun cited extensive historical sources regarding both ancient and more contemporary abortion practices. Indeed, justices contemptuous of Roe's holding have long expressed strong disagreement with this historical analysis. $^{234}$ What if, then, a lower court had access to a new and definitive examination of the

231 The Stell Court incorrectly reevaluated the factual question based on evidence that was available and which had been considered by the Supreme Court in Brown.

232492 U.S. 490 (1989).

$233 I d$. at 526. The statute provided that a twenty-week-old fetus was presumed valid, so that viability testing effectively placed the burden of proof on the woman to disprove viability.

234 See, e.g., Roe v. Wade, 410 U.S. 113, 174-75 (Rehnquist, J., dissenting) (“As 
historical issues surveyed in Roe, should that Court have the authority to reconsider the rule of viability? Or suppose that a treasure trove of historical documents were discovered that indicated unequivocally that the drafters and ratifiers of the Fourteenth Amendment uniformly believed that adoption of the Equal Protection Clause would not result in integrated public schools. Would a lower court have the power to employ these new facts to reassess the continuing validity of the holding in Brown?

The answer to these and similar questions is no. Lower courts cannot have the authority to reevaluate the empirical bases for constitutional rules or standards. Many reasons support this conclusion. Foremost, the basic working premise of my theory is that facts must be taken seriously in constitutional adjudication. This premise has two consequences in the case of constitutional rule-facts. First, the sort of facts involved must be susceptible to being found with some measure of certainty, and second, they must, as far as they go, be subject to independent treatment as a matter of constitutional authority.

As regards the first reason, most constitutional rule-facts are amorphous, highly intricate, often defy replication, and are simply not amenable to rigorous study and exacting analysis. Rule-facts, as discussed in detail in Section II.B.1, are disproportionately historical in nature or involve highly intricate issues regarding the structural operation of governing constitutional law. The history of abortion practices, the original intentions of the ratifiers of the Second Amendment, the comparative advantage of states to operate as laboratories of experimentation, and so on, are all questions at bottom empirical, but for which answers will remain general approximations at best.

The second reason for not allowing lower courts the authority to reconsider the empirical grounds for constitutional rules or standards is even more compelling. Almost invariably, constitutional rule-facts operate seamlessly with other authorities used to assess constitutional

early as 1821 , the first state law dealing directly with abortion was enacted by the Connecticut Legislature.... By the time of the adoption of the Fourteenth Amendment in 1868, there were at least 36 laws enacted by state or territorial legislatures limiting abortion.”).

$-79-$ 
meaning. It can only very rarely be said that any particular rule would have been different if the facts had been different. If the constitutional rule would not have been different under different rule-facts, subsequent changes in the fact or our knowledge of the fact should not affect the continuing validity of the rule. Any procedure that would permit lower courts to reconsider constitutional rule-facts on their way toward revisiting the continuing validity of constitutional rules would have to demonstrate the essentialness of rule-facts to constitutional rules. In almost all cases, however, constitutional rule-facts do not play this essential role. Constitutional-rule facts are almost invariably set-forth as part of a litany of premises offered to support a rule or standard. Rarely do they stand alone, and when they do they are often considered - at the time or later - as proxies for normative principles or values. The historical premises underlying conclusions regarding original intent are routinely buttressed by arguments from the text, precedent, and constitutional structure. ${ }^{235}$ The Constitution's meaning is stitched together from a patchwork of authorities and a change in the understanding of one or two will not necessarily undermine the soundness of the rule.

As a practical matter, therefore, the boundary between fact and value is nearly impossible to ascertain when a doctrine is premised on constitutional-rule facts and other considerations. Given the relationship between values and facts in interpreting the Constitution's meaning, disentangling rule-facts from other authorities would be impossible in the vast majority, if not in all, cases. The authorities the Court relies upon to discern the Constitution's meaning tend to be a mixture of normative and empirical and their respective contributions to a given rule cannot be ascertained. As a consequence, finding constitutional rule-facts is a component of law-making and ought to be subject to the ordinary rules of judicial hierarchy. Lower courts, therefore, are bound to adhere to constitutional rules and standards, notwithstanding changes, however dramatic, in the facts or our knowledge of the facts supporting them.

\section{b. Constitutional adjudicative-facts}

235 Cass R. Sunstein \& Adrian Vermeule, Interpretations and Institutions, $101 \mathrm{MICH}$. L. REV. 885 (2003) (arguing that institutional considerations should not be neglected in interpreting law). 
Adjudicative-facts occupy the opposite pole from that of rule-facts in constitutional cases. Whereas rule-facts affect whole areas of law and are an inextricable component of law-making, adjudicative-facts have minimal impact outside the immediate litigation in which they are found. ${ }^{236}$ Because constitutional adjudicative-facts are unique to particular cases, they appear to present little difficulty on the question of lower court power to reconsider higher court precedent. And this will be true in most situations, mainly because there will be no higher court rulings on the specific factual question. In a defamation case, for instance, the application of the New York Times v. Sullivan "actual malice" test will be highly context-specific. The question of whether a statement was made "with knowledge or reckless disregard of its falsity," will have to be determined on a case by case basis. ${ }^{237}$ At the same time, however, two aspects of constitutional adjudicative fact-finding implicate principles that transcend individual cases. The first involves the obvious one that the initial definition of the applicable test is a matter of law. The choice of the "actual malice" standard itself, then, is a rule that could only be reconsidered by the Supreme Court. The second aspect of constitutional adjudicative-facts is a component of the first, but worthy of separate consideration. The burden of proof that must be met in constitutional cases is set as a matter of law.

The subject of burdens of proof is considerably more inscrutable than the usual discussions among legal practitioners would indicate. There is little question that the "ultimate" burden of proof must be set as a matter of law and is binding on lower courts. For example, as

236 Constitutional adjudicative-facts have somewhat greater impact than ordinary adjudicative-facts simply because of their constitutional genesis. Although their resolution might not have any direct consequences for other cases, there may be substantial indirect consequences. For example, in the area of free speech, an adjudication that certain materials are obscene in one locale could chill their dissemination in other areas, even though the materials might not be deemed "obscene" in those areas.

237 A higher court, of course, retains the power to independently review a trial court's findings of fact. If the case were remanded, the lower court would be obligated to act in accordance with the directions of the higher court - both as to the facts and the law. But the specific facts of the case are not likely to recur exactly in any other case, and so lower courts are not bound to adjudicative fact-finding done by higher courts in other cases. 
discussed above, in Addington v. Texas, ${ }^{238}$ the Court held that the state must meet the "clear and convincing" evidence standard in order to civilly commit an allegedly mentally ill and dangerous person. But this seemingly straightforward requirement hides a fair amount of empirical complexity. In particular, consider the element of "dangerousness" that, together with mental illness, must be demonstrated by the state in commitment cases. Most recently, this issue has been discussed in the sub-class of potential committees popularly referred to as "sexually violent predators" (SVP).

In SVP cases, the Court has held that the state must prove that the defendant is both mentally abnormal ${ }^{239}$ and dangerous. The Court, however, has yet to say how dangerous an alleged SVP must be in order to satisfy the second prong of the test, though it is likely to be at least by clear and convincing evidence and possibly by a stricter standard yet. If clear and convincing evidence is estimated as approximately a 75 percent likelihood, and proof beyond a reasonable doubt as exceeding a 90 percent likelihood, very few alleged SVPs would in fact qualify for commitment. The level of social scientific technology is not sophisticated enough to permit predictions with this level of certainty. ${ }^{240}$ But if these levels of proof mean something different, then the state might be able to meet its evidentiary burdens with today's technology.

Although the Supreme Court has yet to consider the issue of what quantum of proof of future violence is constitutionally mandated in SVP cases, state courts have weighed-in on the matter. In People v. Ghilotti ${ }^{241}$ for instance, the California Supreme Court interpreted a California statute that provided for the commitment of a person who has a "diagnosed mental

$238 \quad 441$ U.S. 418 (1979).

239 In Kansas v. Hendricks, 521 U.S. 346 (1997), the Court held that civil commitments of sexually violent predators were not constitutionally limited to those who suffered mental illness. "Mental abnormality" would suffice, together with "dangerousness," as a basis for commitment.

240 David L. Faigman, David H. KaYe, Michael J. SAKS \& Joseph SANDERs, Modern SCIENTIFIC EVIDENCE: THE LAW AND SCIENCE OF EXPERT TESTIMONy (2005-2006). 24144 P.3d 949 (Ca. 2002). 
disorder so that he or she is likely to engage in acts of sexual violence without appropriate treatment and custody." 242 The State argued that "likely" does not mean "probable" or "more likely than not." The State urged that likely meant "a significant chance, not minimal; something less than 'more likely than not' and more than merely 'possible." ${ }^{243}$ The defendant, in contrast, argued that "likely" meant "highly likely," or at least "more likely than not."244 The California court sided with the state and found that "likely to engage in acts of sexual violence' does not mean the risk of reoffense must be higher than 50 percent." 245 The court explained as follows:

[T] he phrase requires a determination that, as the result of a current mental disorder which predisposes the person to commit violent sex offenses, he or she presents a substantial danger - that is, a serious and well-founded risk of reoffending in this way if free. ${ }^{246}$

Under California law, therefore, the kind of proof required is the substantial danger test. $^{247}$ Yet, the burden of proof under the applicable statute is the beyond a reasonable doubt standard. The court found no incongruity in asking juries to determine whether, by proof beyond a reasonable doubt, the defendant "presents a serious and well-founded risk of committing new acts of criminal sexual violence. ${ }^{248}$ In effect, the California test asks the jury to determine with

$\begin{array}{ll}242 & I d . \text { at } 915 . \\ 243 & I d . \text { at } 916 . \\ 244 & I d . \text { at } 915-16 . \\ 245 & I d . \text { at } 916 .\end{array}$

$246 I d$. Oddly, the court sought support for its definition of the word "likely" from thesauruses rather than dictionaries. As Justice Werdegar pointed out in dissent, "[o]ne should look to a dictionary, rather than a thesaurus, for a definitive statement of a word's meaning." Id. at $931 \mathrm{n} .3$ (Werdegar, J., dissenting). She found that such a search supported a "more likely than not" meaning for the word "likely." Id.

247 Id. at 923 n.14. Many states find that the Constitution demands a substantially higher standard of proof. See, e.g., In re Leon G., 26 P.3d 481, 488-89 (Ariz. 2001) ("likely" means "highly probable"); Commonwealth v. Reese, 2001 WL $359954 * 15$ (Mass.Super.Ct. April 5, 2001) ("Likely" means "at least more likely than not"); Matter of Linehan, 557 N.W.2d 171, 180 (Minn. 1996) ("likely" means "highly likely").

$248 I d$. at 924 n.15. Under the law, the jury would also have to find beyond a -83 - 
near certainty ("beyond a reasonable doubt") that there is a significant probability (something less than $50 \%$ ) that the defendant will be violent. And, indeed, when it comes to scientific statements of fact, it is not unusual to speak in these terms. ${ }^{249}$ It would not be incongruous, for instance, for a meteorologist to express 95 percent confidence that the chance of rain tomorrow is 60 percent. $^{250}$ In the same way, as Ghilotti arguably requires in California, juries must determine by proof beyond a reasonable doubt (90-95\%?) that the defendant is likely (25-30\%?) to be sexually violent.

Constitutional adjudicative-facts, therefore, while substantially more straightforward than rule- and review-facts, nonetheless possess a fair measure of complexity. As a practical matter, constitutional adjudicative-facts are case dependent and thus ostensibly within the procedural dictates of ordinary trial procedures. Also, because they do not repeat identically from case-tocase, there is little question but that a lower court is not bound by a higher court's previous pronouncements. $^{251}$ At the same time, frameworks surrounding adjudicative fact definition and their determination in constitutional cases are subjects of law and thus established in the ordinary course of law development.

\section{c. Constitutional review-facts}

So far, there has been little of great controversy in my elucidation of constitutional facts in this section, in that I have concluded that rule-facts should be decided as matters of law and

reasonable doubt that the defendant "(1) previously was convicted of qualifying violent sex crimes, [and] (2) has a mental disorder which seriously impairs volitional control of violent sexual impulses." Id.

249 See John Monahan \& David B. Wexler, A Definite Maybe: Proof and Probability in Civil Commitment, 2 LAW \& HuM. BEHAV. 37, 38 (1978).

250 See John Monahan \& Henry J. Steadman, Violent Storms and Violent People: How Meteorology Can Inform Risk Communication in Mental Health Law, 51 AM. PSYCHOLOGIST 931, 931-38 (1996).

251 Since constitutional adjudicative-facts should be subject to de novo review on appeal, lower courts might very well be subject to a higher court's subsequent pronouncements and thus be bound on remand to follow an appellate court's findings of adjudicative fact. 
adjudicative-facts should largely be subject to ordinary fact-finding rules, albeit closely scrutinized on appellate review. Although most judges and scholars have given little attention to these issues, if they had, most would agree with at least the broad outlines of my analysis to this point. But such agreement likely ends here. By far the most difficult situation is presented by constitutional review-facts, a category that includes the vast majority of facts in constitutional cases. Review-facts are relevant under a particular interpretation of the Constitution - i.e., some constitutional rule or standard - and, by definition, their resolution has precedential import in other cases. There is no shortage of examples, including some of the better known being the point at which the fetus becomes viable, ${ }^{252}$ the effects of segregation on black school children, ${ }^{253}$ the general effects of virtual child pornography, ${ }^{254}$ the group dynamics associated with jurysize, ${ }^{255}$ the effects of spousal notification provisions, ${ }^{256}$ and so on. ${ }^{257}$ As regards these sorts of facts, lower courts should have the authority to distinguish higher court rulings when there is substantial proof that the facts themselves have changed or our knowledge of the facts have changed, so long as those facts were necessary and sufficient for the earlier ruling.

In Casey, for example, the Court set forth the "undue burden" standard which, in turn, established the relevance of the factual issue of whether a challenged regulation poses a "substantial obstacle" to the exercise of the abortion right. In Casey itself, the Court invalidated the Pennsylvania spousal notification provision primarily on the basis of research indicating its

\author{
252 Roe, 410 U.S. at 113; Casey, 505 U.S. at 833. \\ 253 \\ Brown, 347 U.S. at 483. \\ 254 Ashcroft v. Free Speech Coalition, 535 U.S. 564 (2002) ("Virtual child
} pornography is not 'intrinsically related' to the sexual abuse of children. [While] the government asserts that the images can lead to actual instances of child abuse, the causal link is contingent and indirect.") In contrast, the specific effects on children who are used in child pornography is a rule-fact. See e.g., New York v. Ferber, 458 U.S. 747 (1982).

Ballew, 435 U.S. at 223.

Casey, 505 U.S. at 833.

See generally, FAIGMAN (2004), supra note XX. 
potentially burdensome nature, at least in a small percentage of cases. The Court, however, refused to invalidate the 24-hour waiting provision, with the Joint Opinion observing that, "on the record before us," the research does not demonstrate that the waiting requirement posed a substantial obstacle to the exercise of the abortion right. ${ }^{258}$ Presumably, the Court understood that research might someday demonstrate the burdensomeness of waiting periods and, moreover, that other regulations might be challenged as being unduly burdensome. Lower courts should have the latitude, indeed the obligation, to review the evidence to determine whether the regulation passes muster under the Casey standard.

The power to review the predicate facts of precedent would not, however, give lower courts carte blanche to challenge higher court authority with which they disagree. When assessing the continuing validity of a precedent, lower courts would have to resolve two issues in a satisfactory and unequivocal way. First, the court would have to determine that the changed fact was necessary and sufficient for the earlier ruling; and second, it would have to put forward sufficient proof to support the new findings of fact.

The first consideration, whether the review-facts were necessary and sufficient for the earlier ruling, will sometimes be a delicate task. This assessment is easiest, of course, when essentially only one review-fact is offered to support an outcome. In Ballew v. Georgia, for example, the Court rested its holding that the Constitution does not permit juries of less than six members on the single basis that panels are less effective when their numbers fall below a certain total, with six somewhat arbitrarily chosen as minimally required under the Constitution. ${ }^{259}$ Similarly, viability is based on a fairly concrete and unitary empirical proposition - the point-intime when a fetus can survive outside the womb. In contrast, in Roper v. Simmons, ${ }^{260}$ the

258 Casey, 505 U.S. at 887 (emphasis added).

259 The factual question of jury effectiveness is composed of two separate factual issues, whether smaller panels are adequately representative of the larger community, and whether the dynamics of small group decision-making change in important ways as the group decreases in size. See generally Ballew v. Georgia, 435 U.S. 223 (1978).

260125 S.Ct. 1183 (2005). Roper is discussed at length supra notes XX-XX and -86- 
empirical arguments were somewhat more multifarious. The Court listed three factual bases for concluding that those who kill as juveniles cannot be subject to capital punishment under the Eighth Amendment. These included surveys of state law indicating acceptance or renunciation of such punishments, the physiological and psychological developmental differences between children and adults, and surveys of international practice and opinion. Suppose, after some period of time, the evidence for one of these three premises indicates a changed empirical landscape, should a lower court be entitled to rely on that basis alone to distinguish the Roper precedent? The answer is that there is no definite answer. Like most aspects of constitutional law, there is no doctrinal recipe to use under such circumstances. The lower court would have to determine to the best of its capacity whether the fact that has changed was the central premise for the otherwise controlling precedent. It might be, for instance, that a changed landscape as regards state death penalty practices would be enough, but not if the changed landscape concerns international standards. But this is a judgment call.

Moreover, before challenging an established precedent, a lower court would also have to find that the research data are substantial enough to support the new empirical conclusion. The question for courts in subsequent cases would be whether research conducted after the earlier decision was substantial enough to warrant reaching a different conclusion than was reached in the earlier case. In the situation of the 24-hour waiting provision, for example, lower courts would not be able to reassess the research data that had been available to the Court in 1992 when Casey was decided. A court's assessment of an existing body of research data should be binding on lower courts. In fact, lower courts should act in this realm only when the research data are very robust and largely unambiguous. This is especially so when a Supreme Court precedent is in issue. Given the gravity of distinguishing a Supreme Court decision on a factual basis, lower courts should, and can be expected to, tread carefully over the new research terrain.

There are an assortment of significant advantages that come from adopting a procedural rule by which lower courts can reevaluate precedent when research data clearly indicate that accompanying text. 
predicate constitutional review-facts have substantially changed. First of all, it advances the legitimacy of constitutional law-making by keeping it in line with contemporary knowledge of the facts underlying constitutional decisions. As Oliver Wendell Holmes, Jr. put it, "It is revolting to have no better reason for a rule of law than that so it was laid down in the time of Henry IV. It is still more revolting if the grounds upon which it was laid down have vanished long since, and the rule simply persists from blind imitation of the past."261 When a constitutional rule depends on a stated set of facts, the legitimacy of the outcome is undermined to the extent that those facts are not what the court says they are. The rule ought to fit the facts as they are known today.

In addition, giving lower courts authority to reconsider constitutional review-facts will have a salutary effect on the Supreme Court's sometimes harum-scarum reliance on such facts in its jurisprudence. Just the knowledge that lower courts might revisit factual premises for their holdings should lead the justices to be more careful in explaining the reasons for their decisions. In Brown, for example, few, if any, constitutional scholars believe that the social science research was anything more than a make-weight for an outcome reached on other grounds. But what were those other grounds and why didn't the Court simply cite them instead? The truth is that in the early 1950s none of the usual constitutional authorities unambiguously supported the outcome. The text itself was ambiguous, the precedent was weak or contrary, and original intent was inconclusive. Social scientific authority provided a seemingly neutral basis for the outcome, though in retrospect it was not seriously relied upon. Similarly, in Roe, it appears fairly clear that Justice Blackmun used "viability" as a convenient placeholder for a sensible compromise between the fundamental right of women to control their bodies and the compelling interests of the state. Although Webster might suggest otherwise, I suspect that few constitutional scholars (or justices) believe that if viability were to move, say, to 10-weeks, the abortion right would follow suit. By giving lower courts the authority to reconsider precedents based on outmoded review-fact premises, the Court should hesitate before expounding empirical reasons that are not

261 Oliver Wendell Holmes, Jr., The Path of the Law, 10 HARV. L. REV. 457, 469 (1897). 
real reasons for the outcome.

It might be argued, however, that taking away the Court's ability to find facts "normatively" or "interpretively" will limit the Court's flexibility to achieve outcomes it wishes to reach. Only if facts are understood interpretively can they be used rhetorically to support whatever outcome is sought. Especially when the Court operates at the vanguard of societal evolution, as it did in Brown and Roe, when traditional authorities militate against the "enlightened" path the Court wishes to take, interpretive facts might play an essential rhetorical role. And, indeed, one should be reluctant to advocate any jurisprudential approach that would have made deciding Brown more difficult.

Although I am sympathetic to the argument that the Court sometimes needs the latitude interpretive fact-finding gives it, I ultimately find it unpersuasive. The principal reason the Court relies on scientific arguments, as in Brown and Roe, is that the usual so-called neutral principles of interpretation are not available. The Court, ever solicitous of its legitimacy, which has been historically associated with restraint and reliance on neutral principles, is reluctant to sometimes give the true reason for its decisions. ${ }^{262}$ It was easier to say in Brown that social science revealed the inequality that was inherent in segregation than to say that the Court had reached the moral conclusion that segregation was wrong under virtually all circumstances, despite an ambiguous text, contrary precedent, and original intent that was, under only the most generous historical view, inconclusive. The argument from a moral basis makes the justices seem platonic guardians. Science possesses the mien of neutrality, rather than the stink of judicial activism. Similarly, in Roe, viability as a scientific concept sounded more neutral than an opinion that instituted an "arbitrary" line at 24-weeks, on the basis of little more than that at least five justices agreed that it was a reasonable compromise between two fundamental and irreconcilable principles.

262 Herbert Wechsler, Toward Neutral Principles of Constitutional Law, 73 HARV. L. REV. 1, 6 (1959). 
The approach proposed here would thus take an important rhetorical arrow out of the Court's quiver. It might also weaken the Court's legitimacy, to the extent anyone paying attention continues to believe that members of the Court actually adhere exclusively to nonsubjective neutral principles for their constitutional opinions. To the extent that taking facts seriously will accomplish anything, it is hoped that it will lead the Court to be more plain-spoken about the reasons for what it does. This might pierce the judicial veil, but it will contribute in one very salutary way more generally. In the United States, the people are the ultimate sovereign. The people, therefore, should be fully engaged in the dialogue that takes place every time the Court decides a constitutional case. If the bases for decision are hidden beneath a scientific facade, and the true reasons are not made plain, then meaningful dialogue cannot occur. The Court, perhaps, has no greater obligation than giving reasons for its decisions. It should be candid about those reasons. Anything less and its legitimacy should be jeopardized.

Another significant advantage of giving the authority to lower courts to reevaluate constitutional review-facts is that it will facilitate the introduction of new information into the law. Although discovery of constitutional review-facts is not limited to the adversarial process since they can be brought to the attention of courts through amicus briefs or even independent research - they are likely to be developed most fully if first put into issue at the trial court level. The multiple-layers of the trial and appellate process are well-suited to the full exploration and development of the empirical record upon which disputed constitutional review-facts rest. Moreover, the courts' taking constitutional facts seriously sends an important message to researchers. Good research will be valued and potentially relied upon whenever it is done. Previous decisions relying on early research data, therefore, do not foreclose reconsideration in light of the publication of substantial new data.

One striking change that would follow from a jurisprudence that permits lower courts to reconsider constitutional review-facts would be on the Supreme Court's control over its own docket. By distinguishing a controlling precedent on the basis of changed constitutional reviewfacts, a federal appellate court or a state's highest court could effectively force the Supreme 
Court to grant certiorari. ${ }^{263}$ The Court uses its control over its docket partly to manage the timing of constitutional decisions, sometimes waiting a considerable period for an issue to mature in the lower courts. The rule proposed here would give lower courts some leverage in forcing the High Court to enter a field (or return to a field) when, perhaps, the Justices would have preferred to let it simmer for awhile longer or avoid the issue altogether.

Although loss of full control of its docket is a danger of the proposed rule, it is not one of great consequence. Even when the Supreme Court feels its hand has been forced, it need not issue an opinion that resolves the dispute on the merits. In the most extreme instances, the Court could reverse the lower court summarily, simply as being contrary to controlling precedent, and provide no further explanation. This is not likely to happen often, however, since the Court may feel compelled to explain why the changed factual situation does not alter the application of the constitutional rule. It might also be argued that the Court's loss of some control over its docket could itself be a salutary event. There is nothing sacred about the Court's certiorari power and, indeed, such absolute control is a relatively recent phenomenon. The proposed rule injects a measure of democracy into the High Court's docket, an outcome that might increase its responsiveness to the pressing and most dynamic issues of the day.

Finally, it is worth emphasizing that lower courts are unlikely to exercise their power to distinguish higher court precedent very frequently. They are likely to do so only when they have enough empirical ammunition to overwhelm the opposing precedent. This will not occur often. In most of the areas in which the Court employs empirical arguments, there is limited amounts of research available and much of it tends to be fairly soft social science. Even a considerable number of research studies on many social science subjects will not be enough to sustain a court's reconsideration of a higher court's holding in a particular review-fact context. Also, many of the empirical questions the Court resolves concern highly complex matters that even the

263 Federal district courts and intermediate state courts, of course, could also reevaluate constitutional review-facts, but superior courts short of the United States Supreme Court, could check any unrestrained enthusiasm in this regard. 
best efforts of mainstream scientists will not soon conquer. In Kansas v. Crane ${ }^{264}$ for instance, the Court discussed the scientific research involved in defining "lack of volitional control," the principal component of the mental abnormality requirement in the commitment of sexually violent predators. ${ }^{265}$ Psychologists, psychiatrists, and neuroscientists are some distance from obtaining a good understanding of this construct. Many of the facts the Court employs share this level of complexity. Once the Court has weighed in with a review of the evidence and has provided an answer based on contemporary research, a lower court should be disinclined to revisit any particular constitutional review-fact without substantial research data supporting its holding. As Holmes, quoting Emerson, said, "When you strike at a king, you must kill him.",266

\section{CONCLUSION}

The Supreme Court approaches fact-finding much as the Catholic Church did in the Sixteenth Century. Facts are not so much found as they are interpreted. Facts are a constituent part of doctrine. The High Court employs empirical claims to buttress its reading of the constitutional text, but scientific refutations of these claims have little or no effect on the Court's continuing adherence to the doctrines built upon them. Just as was true for the Church, however, the Court's continued adherence to doctrines founded on faith rather than modern empiricism threatens its very legitimacy.

In this Article, I set forth a uniform theory of constitutional facts. This theory is offered as a substitution for the Court's interpretive approach, in which facts merely serve the doctrinal ends sought by the justices. The Court's approach does have the salutary effect of avoiding

\footnotetext{
534 U.S. 407 (2002).

265

Id. at 411-12.

266 BARTLETT's FAMILIAR QUOTATIONS 433:30 (1992 $16^{\text {th }}$ ed., Justin Kaplan, editor) (quoting "Recollected by Oliver Wendell Holmes, Jr. from Max Lerner," The Mind and Faith of Justice Holmes (1943)).
} 
changeable constitutional standards due to changed understandings of the empirical world. This stability comes at a cost, however, for a rule that has outlived its reasons for being is no longer legitimate. But there is no inherent contradiction between enlightened factual investigation and a sound constitutional jurisprudence. Constitutional doctrine should be informed by contemporary understandings of the empirical world. This Article provides a framework by which this might be accomplished.

Facts arise in constitutional adjudication in a variety of forms. Using Professor Kenneth Culp Davis' famous dichotomy between legislative and adjudicative facts as a springboard, I set forth a taxonomy by which the variety of constitutional fact-finding can be understood. In constitutional cases, Davis' scheme must be refined to account for three basic types of constitutional facts - rule-facts, review-facts, and adjudicative-facts. Constitutional rule-facts are relevant to the definition of a rule or standard to be applied in a set of cases. These facts are instrumental in the process of interpreting the Constitution's meaning and are typically used in conjunction with, and are sometimes a component of, traditional constitutional authorities, such as the text, precedent, original intent, and constitutional structure. Perhaps the best-known type of constitutional rule-facts are historical facts used to determine "original intent." In contrast, the remaining two categories of facts are associated with the application of constitutional rules or standards. Constitutional review-facts involve facts that are relevant under a particular interpretation of the Constitution and which transcend individual cases. In Roe v. Wade, for instance, the Court adopted "viability" - the point in time when the fetus can survive outside the womb - as the time at which the state's interests in prohibiting abortions becomes "compelling." The scientific answer to the question of when "viability" occurs is a constitutional review-fact. Constitutional adjudicative-facts similarly involve the application of the Constitution, but they are peculiar to individual cases. Examples of constitutional adjudicative-facts abound, including determining "actual malice" under New York Times v. Sullivan, and assessing whether a particular photograph appeals to the prurient interest under local community standards, as directed by the Millertest. 
Because constitutional facts vary so widely - from rule-facts such as whether small republics are better guarantors of liberty than large republics to adjudicative-facts such as whether a municipal police department intentionally discriminated against plaintiffs on the basis of race - the procedural guidelines that apply to them must account for this variability in a practical way. In particular, two procedural aspects of proof must be considered in the development of a rational scheme of constitutional fact-finding. The first concerns the question of the kinds of evidence that are available to prove constitutional facts and the methods by which such proof is to be evaluated. The second concerns the matter of allocating burdens of proof and, in particular, determining how the costs of error are to be allocated between the parties to constitutional cases. The problem of establishing evidentiary standards and allocating burdens of proof depends greatly on the sort of constitutional facts that are in dispute. Constitutional adjudicative-facts lend themselves readily to traditional evidentiary rules and burdens of proof, since they are particular to the case and are determined by triers of fact (judges or juries) in the course of ordinary trial processes. In contrast, while review- and rule-facts can be the subject of trial processes, they very often are introduced into the process through amicus briefs and independent judicial investigation, and sometimes are even found in the first instance by appellate courts. Hence, while the issues of establishing standards for, and allocating burdens of, proof are present in regard to all constitutional facts, these issues manifest themselves very differently for the different forms constitutional facts take.

In addition to, and a component of, the multiple kinds of facts used in constitutional cases is the wide assortment of fact-finders situated along the path of constitutional adjudication. I examine three principal subjects raised by the issue of the identity of the constitutional factfinder. The first concerns the role of the jury in constitutional cases and, in particular, whether reviewing courts owe deference to the fact-finding of juries. The second involves a large subject in constitutional law, that of judicial review of legislative fact-finding. Finally, third, I consider a subject that might appear somewhat esoteric, but which largely encapsulates many of the basic issues surrounding the choice of constitutional theories of fact-finding that might be available to the Court. This last issue involves the question whether lower courts might sometimes be able to 
depart from precedent on the basis that the facts on which that authority was set have changed, or our knowledge of them has changed. I conclude that lower courts sometimes should not have this power (in the case of constitutional rule-facts), but very often should have this power (in the case of constitutional review- and adjudicative-facts).

In Abrams v. United States, ${ }^{267}$ Justice Holmes, in a dissenting opinion, hypothesized "that the best test of truth is the power of the thought to get itself accepted in the competition of the market." 268 He added, somewhat laconically: "That at any rate is the theory of our Constitution. It is an experiment, as all life is an experiment." ${ }^{, 69}$ Holmes, as perhaps the first legal realist, well understood the interaction between the Constitution's words and societal consequences. The Constitution may promulgate theories, but only life provides empirical test. A well-functioning Constitution must be fully grounded in the empirical world and responsive to empirical demands. A Constitution is measured by its practical consequences. Constitutional provisions divorced from the world in which they operate are destined to become empty articles of faith. Their legitimacy resting on dictate rather than reason. Our Constitution was "intended to endure for ages to come," and, as a consequence, must "be adapted to the various crises of human affairs." 270 Only through a candid and realistic constitutional fact jurisprudence will this intention be met.

$\begin{array}{ll}267 & \text { 250 U.S. } 616(1919) . \\ 268 & \text { Id. at } 630 . \\ 269 & \text { Id. } \\ 270 & \text { McCulloch v. Maryland, } 17 \text { U.S. 316, } 515 \text { (1819). }\end{array}$

$-95-$ 